\title{
Scoping Review and Interpretation of Myofascial Pain/Fibromyalgia 2 Syndrome: An Attempt to Assemble a Medical Puzzle
}

3

\section{Mimicking a "Mild-Moderate Global Chronic Compartment Syndrome"?}

Shil6h Plaut ${ }^{1}$

Schøol of Medicine, St. George's University of London, London, United Kingdom

Corßesponding author:

Shiloh Plaut

Shilab Plaut- sole researcher and author of this manuscript including conception, orgarlization, literature review, integration of information, findings analysis, manluzscript preparation and writing. 


\section{Scoping Review and Interpretation of Myofascial Pain/Fibromyalgia 18 Syndrome: An Attempt to Assemble a Medical Puzzle}

\section{Summary/Abstract}

21

Background: Myofascial Pain Syndrome (MPS) is a common overlooked and undeBdiagnosed condition, and with significant burden. MPS is often dismissed by cliniztans while patients remain in pain for years. MPS can evolve into fibromyalgia, howesver, effective treatments for both are lacking due to absence of a clear medranism. Many studies focus on central sensitization. Therefore, the purpose of this zroping review is to systematically search cross-disciplinary empirical studies of MPQ,ffocusing on mechanical aspects, and suggest an organic mechanism explaining howet might evolve into fibromyalgia. Hopefully, it will advance our understanding of this disease.

Methods: Systematically searched multiple phrases in MEDLINE, EMBASE, COCFRANE, PEDro and medRxiv, majority with no time limit. Inclusion/exclusion based on title and abstract, then full text inspection. Additional literature added on releBant side topics. Review follows PRISMA-ScR guidelines. PROSPERO yet to adapt regişration for scoping reviews.

Findiags: 798 records included. Fascia can adapt to various states by reversibly chaßging biomechanical and physical properties. Trigger points, tension, and pain are a ha\&mark of MPS. Myofibroblasts play a role in sustained myofascial tension. Tension can propagate in fascia, possibly supporting a tensegrity framework. 
Mowent and mechanical interventions treat and prevent MPS, while living sedentarily predisposes to MPS and recurrence.

Con\&usions: MPS can be seen as a pathological state of imbalance in a natural prođBss; manifesting from the inherent properties of the fascia, triggered by a disrapted biomechanical interplay. MPS might evolve into fibromyalgia through derałsged myofibroblasts in connective tissue, or "fascial armoring", and may explain paim6 distribution of pain, decreased pressure/pain threshold, cardiovascular abn®7malities, and other phenomena eg, occasional complete resolution after surgery. Movement is an underemployed requisite in modern lifestyle. Lifestyle is link\&d to pain and suffering. The mechanism of needling is suggested to be more mectoanical than currently thought. A global percutaneous needle fasciotomy that respealcts tensegrity principles may treat MPS/fibromyalgia more effectively. Funfitional somatic syndromes can be seen as one entity, perhaps sharing a common rhesвana-phycho-neurological mechanism.

54

Key5tords: fascial armoring, myofascial pain syndrome, myofibroblast, fibromyalgia, tensfegrity, global chronic compartment syndrome. 


\section{S68ping Review and Interpretation of Myofascial Pain/Fibromyalgia}

\section{Intmoduction}

Chrøaic pain is a major cause of morbidity and has a significant impact on quality of life. 6 Myofascial pain denotes a pain arising from muscle and fascia. Commonly knoGAn as "muscle knots" myofascial pain usually arises in trigger points (TrPs) or 'tenfir spots'. 2,3,4 $\mathrm{TrPs}$ are small and sensitive areas in a contracted muscle, that spo6६aneously or upon compression cause pain to a distant region, known as a referryed pain zone. ${ }^{3,4}$

Myoscial pain syndrome (MPS) is an entity that still lacks a clear definition. Some defiøe it as a regional pain disorder, ${ }^{2}$ others define it on the basis of tenderness and assođated painful spots. ${ }^{3}$ Nonetheless, TrPs and myofascial pain are a hallmark. ${ }^{2,4,5} \mathrm{~A}$ funđamental difficulty arises when there is no clear definition, epidemiology, pat7̋ephysiology, or diagnosis of MPS. Having no accepted definition or criteria, clearby raises issues for both diagnosis and potential studies. ${ }^{6-8}$ The purpose of this pap $\mathbb{E} 4$ is to systematically search the empirical studies and components of MPS in an effor̄ to assemble them into a suggested organic mechanism, explaining its pat76physiology and how it may evolve into fibromyalgia. Since much of the subject is stîl† somewhat under dispute, textbooks and medical literature were added to estatdish a consensus on the elements of MPS. 
In cl’aical practice MPS is often defined by multiple areas of musculoskeletal pain andzenderness associated with painful points. ${ }^{3}$ Pain is deep and aching. It may arise afte\$1rauma, overuse or sedentarism. ${ }^{3}$ A study found laborers who exercise heavily are likely to develop manifestations of MPS than sedentary workers. ${ }^{3}$ Palpation of a8BrP can reproduce or accentuate the pain. ${ }^{4}$ However, these findings are not unicp4e to MPS: in a controlled study they were also present in "normal" subjects. ${ }^{3}$ Litessture estimates $45 \%$ of men and $54 \%$ of women in the general population have $\operatorname{TrP} 86^{2}{ }^{9}$ Estimates are 37 to 65 percent of the population have myofascial pain, which cos $\$ 7$ the united states $\$ 47$ billion every year. ${ }^{4,10,11}$ MPS is one the most frequently und\&8-diagnosed, under-treated and misunderstood sources of the ubiquitous aches andqgains of humankind. ${ }^{4,9}$ However, even recently, MPS is considered by some to be fiction, or otherwise paired with psychosomatic disorders since it involves pain and has 910 clear pathophysiology. ${ }^{11-13}$

Although MPS and fibromyalgia are defined as separate entities, the two may coexis $\oplus$ Br considerably overlap. ${ }^{2,3}$ They are both characterized by painful points, silent rou€Ae laboratory investigations and no systemic inflammation ${ }^{2,3,4}$ In some patients, regiønally localized MPS may seem to evolve into fibromyalgia. ${ }^{3}$ The puzzle of the mectranism of MPS and how it may develop into fibromyalgia still eludes our understanding. The marked dissociation between the estimated prevalence and bur $\$ 8$ of MPS, and the length of text on it in common medical textbooks, reflects this $9 a c k$ of understanding.

Studies of fibromyalgia reveal odd findings eg, complete resolution after laparoscopic surgery, and strong overlap with other conditions (eg, hypermobility 
syndoome). Many theories exist for fibromyalgia, the most accepted and studied seerrsto be central sensitization, but no single theory seems to explain a wide range of etropirical evidence, and the pathophysiology and etiology are still not clear.

Treatbients are insufficient, meanwhile patients suffer. This scoping review focuses on therganic mechanical aspects of myofascial pain with the hope it might advance our 1onderstanding of MPS and fibromyalgia, highlight gaps in current knowledge, and 1508 mulate research in a less explored field.

\section{Methods}

A systematic search was held for multiple combinations of keywords in multiple datalbases. Keywords included : "fascia tension pain", "trigger point satellite", "fascia stiffiness pain", "Fascia Densification", "trigger point densification movement", "biołథถsegrity", for all fields with no time limit; and for "Risk factors myofascial pain syndname" only for title/abstract; Systematic reviews, meta-analyses and randaønized controlled trials were searched in title or abstract for "myofascial pain syndnome", "spinal mobilization sympathetic nervous system", "sympathetic activity indulded by pain" since 2015. The databases used were National Library of Medicine PUBAND (MEDLINE), COCHRANE, EMBASE, PEDro and medRxiv. Web of science was used find items through a cited reference search. All searches were done between Septeronber 2020 and August 2021. Only items published in English were included. This1 follows PRISMA guidelines for scoping reviews. PROSPERO yet to adapt regi\$nation for scoping reviews. A data charting form was used to abstract key data, as as a summary document that was updated in an iterative process: the 
docubaent evolved into this review. The systematic search yielded 979 items. After remb25al of duplicates ( $\mathrm{N}=221), 758$ items were screened by assessing both title and abstract. Items off topic, foreign language, and in journal ranked Q4 were excluded $(\mathrm{N}=364)$. For the remaining items $(\mathrm{N}=394)$ a full text determination of eligibility was then2performed. Four items were excluded. Final number of items included in syst\$29atic search was $\mathrm{N}=390$.

WhABcside topics were encountered, literature was added to broaden scoping review via 1rßedical textbooks, www.uptodate.com and more studies from searching datal3ases $(n=408)$. These side topics were not searched systematically. An attempt was1Bßade to cite more than one source in such cases. Total review items: 798. Figur 31 shows the flowchart of the scoping review.

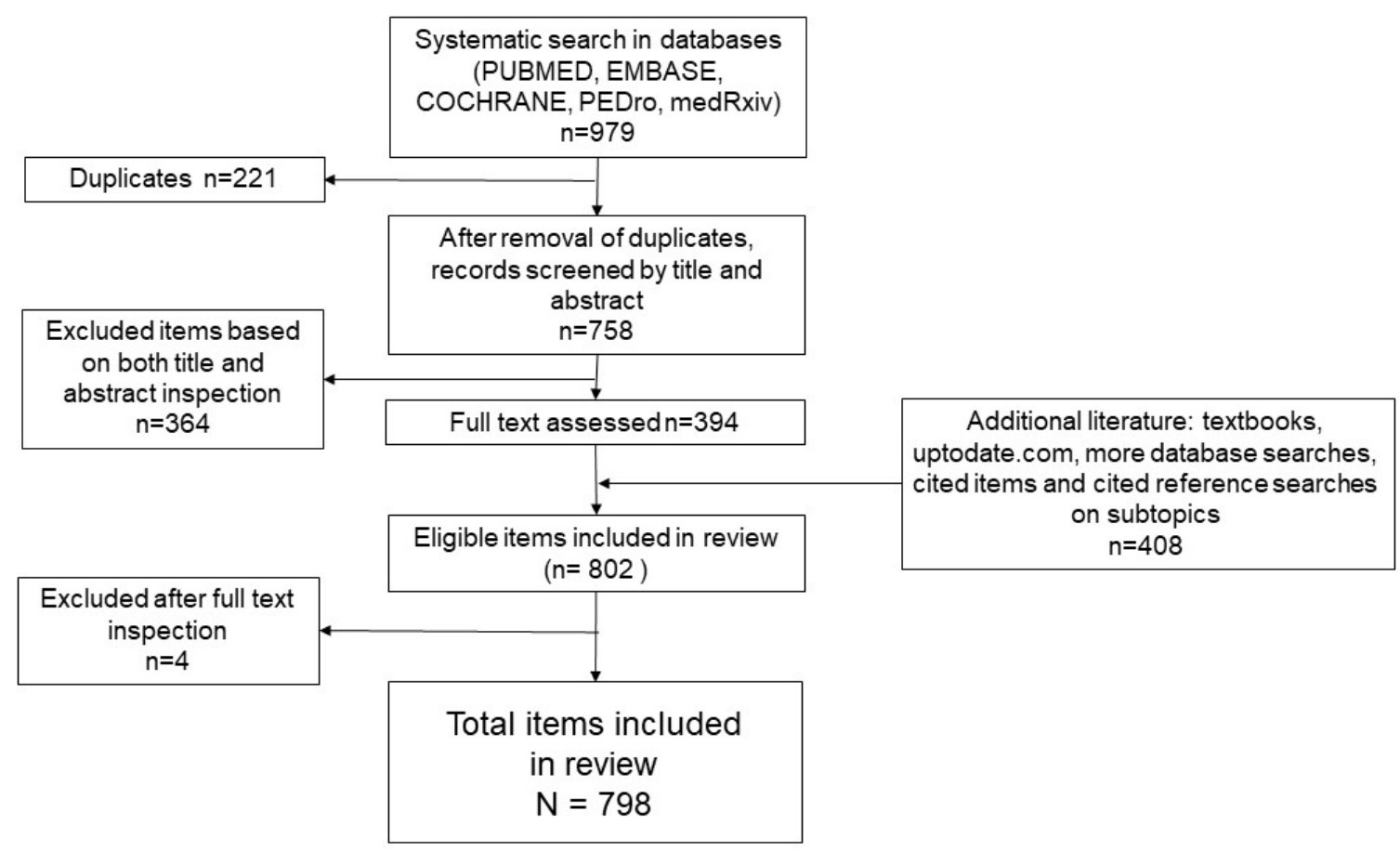

Figure61: Flowchart of scoping review. 


\section{$\underline{\text { Resialts }}$}

A totabof 798 items were included. Numbers of items by recurrent themes were:

"MPS41and trigger points" ( $n=95)$, "properties of fascia" ( $n=47)$, "anatomy and movkenent" ( $n=43$ ), "nervous system" ( $n=31$ ), "biotensegrity" ( $n=26)$, "myofascial painł \#3atment" ( $n=209$ ), "myofibroblasts" ( $=93$ ), "fibromyalgia" ( $n=92$ ), "reviews" $(n=313)$ and "other" eg, somatic syndromes, stress, chronic pain, Dupuytren's dise plantar fasciitis ( $n=129)$. The systematic search included 127 clinical trials, 33 systematic review, and 19 meta-analyses. The findings are presented with the purpøge of understanding the elements relevant to MPS and fascia, in order to asselm them and discuss a suggested mechanism of MPS and fibromyalgia. A micnascopic view will set the stage for a macroscopic understanding.

\section{Praperties of fascia}

\section{$\underline{\text { Genertal }}$}

Fasđiaðs an important yet often misunderstood tissue in medicine. Essentially, fascia is cơribective tissue composed of irregularly arranged collagen fibers, distinctly unlik64he regularly arranged collagen fibers found in tendons, ligaments or apom5 Fasđisgpervasively extends from head to toe, it envelops and permeates muscles, 
bon $\$ 57$ blood vessels, nerves, and viscera, composing various layers at different dept158. ${ }^{16}$ Fascia supports the human body in vital functions such as posture, movergent, and homeostasis, ${ }^{14,16-18}$ as well as containing various sensory receptors for afoprioception, nociception, and even hormones. ${ }^{18}$ Nociception is influenced by the $\$ 6$ ate of the fascia. ${ }^{18}$ This means pain can arise from changes in the connective tissu $162^{18,19}$ The interconnectedness of fascia and its ability to transmit force are at the basiscof its functions. ${ }^{18}$ Fascia is continuous from the trunk across the upper and lowertimbs and hence has the potential to influence range of motion. ${ }^{18}$ Fascia seems to cळ6rnect the distant hip and the ankles, not only anatomically, but also medranically, supporting the concept of a myofascial continuity. ${ }^{18}$

Biopleysical and mechanical functions

Fasđiaghas properties that enable it to reversibly change its stiffness and decrease the $\mathbf{f} 60 \mathrm{ces}$ of tension experienced by it. This is a mechanical 'stress relaxation' resulfing from the viscoelasticity of fascia that expresses high or low stiffness,

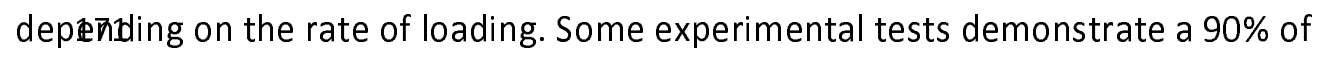
stre\$8 ₹elaxation achieved in about four minutes, afterwards the stress relaxation Curve Bs near linear horizontal. ${ }^{20-23}$ Other studies observe increase in stiffness when ligamients are successively stretched, ie, strains produced by successive and identical loadls7decrease. They recover to baseline after a rest period. Isometrically maintained stre $\$ 36$ esulted in gradual tightening of the tissue. ${ }^{14}$

Blodd zessels and nerves are interspersed in fascia, therefore, involvement of these strutzares due to fascial changes is commonly seen. ${ }^{14}$ It is noted a tender point in the 
gluters medius can refer pain down the leg and mimic sciatica. ${ }^{3}$ Often the patient is awar $\$$ of numbness or paresthesia rather than pain. ${ }^{9}$ Pain is the result of a micasenvironment around the nerve composed of connective tissues (eg, deep fascis,2epineurium). Tissue modifications can be translated into change in nerve mobisisy, with a consequent decrease in the independency of the nerve from its surromdings. Altered fibrous tissue around nerves can lead to entrapments and lesi 8 85. $^{24,25}$ Circulation and perfusion can also be compromised. For example, dysfirfection of the posterior layer of thoracolumbar fascia has been reported as a "chrrofic compartment syndrome" of the paraspinal muscles. ${ }^{26}$

\section{$\underline{\text { Hyalls88nic acid }}$}

Hyalt\$80nic acid (HA) has a key role for fascia. It is the major glycosaminoglycan of the extrellular matrix (ECM) and a major constituent of connective tissue. ${ }^{27}$ Its conđentration, as well as the temperature and other physical parameters, determine the $\$ 2$ sical properties of the ECM. ${ }^{27-30}$ In fascia, HA is present within the sublayers andfargilitates normal free sliding. ${ }^{27}$ Infra-red spectroscopy of viscous HA indicates wat $\$$ molecules can be arranged tetrahedrally almost like as in ice. ${ }^{29} \mathrm{HA}$ interchain intel185tions are reversible, disaggregation occurring with an increase in $\mathrm{pH}$ and temperature; a gel-like to fluid-like transition occurs at $35-40{ }^{\circ} \mathrm{C}^{29} \mathrm{HA}$ solutions can expness high viscosity and non-Newtonian flow properties, ${ }^{28}$ and HA's osmotic activias is relatively high; Its stiffness occurs in part due to its long chains forming an entaiggled large volume network. ${ }^{29,30}$ Once viscosity increases, HA can no longer funetoon as an effective lubricant; this increases resistance in layers with abnormal slidirng $^{27}$ 


\section{Fasoia and movement}

Fasøauacts as a key player for generating movement. ${ }^{16}$ Although often a dropped pref20,5fascia is part of the (fascio)musculoskeletal system. It is suggested to be able to t206smit tension and affect other muscles, reflecting the direction of force vectars, and play a role in properly coordinated movements of the body. ${ }^{31}$

\section{Sedeåarism}

Nonzoersatile movement patterns and sedentarism are an important lifestyle compaionent for fascial changes and pain. ${ }^{3}$ A meta-analysis found that low work task variation is a risk factor for non-specific neck pain. ${ }^{32}$ Immobilization of a limb or body segrient can lead to pathological changes in the connective tissue. Studies of imm2dailization suggest an increase in collagen and myofibroblast density as early as one2w/4ek after immobilization; ${ }^{33}$ After about 4 weeks of immobility in the shortened positilosn the collagen fibrils become arranged anbormally. ${ }^{34}$ Changes start in the periznøsium and after longer periods of immobility the endomysium becomes invotwe d too. ${ }^{34}$ Regular physical activity is recommended for treatment of chronic painasd its effectiveness has been established in clinical trials for people with a varie1 of pain conditions. ${ }^{35}$ Proper posture and resting positions are important in preveroting muscle tension. ${ }^{3}$ Pain often recurs unless appropriate exercises are prescribed. ${ }^{5}$

\section{Tensegrity}


The that thascia can transmit tension to a distance is a basis for a "bio-tensegrity" franaerk ${ }^{36,37}$ Bio-tensegrity applies principles of tensegrity to our understanding of heirsan movement. Tensegrity is an architectural principle. According to this, struzeres (or tensegrity systems) are stabilized by continuous tension with disconzinuous compression. ${ }^{37}$

Wheaghe tension of fascia increases, the connective tissue can distribute the forces throapghout the surrounding areas, propagating along the myofascial system. ${ }^{14,18}$ The forcescpassively imposed in a muscle by stretching are distributed over the tissue as a whalle by means of the intramuscular connective tissue. ${ }^{34}$ According to Wilke et al. ${ }^{38} 2 \operatorname{fars}_{\mathrm{S}} \mathrm{cia}$ links the skeletal muscles, forming a body-wide network of mulpizßrectional myofascial continuity. Cadaveric studies suggest a clinically relevant myoracial force transmission to neighboring structures in the course of musclefasc $\$ 8$ hains (eg, between leg and trunk). ${ }^{38}$ A study suggests manual traction to the bicepssfemoris tendon results in displacement of the deep lamina of the thoracolumbar fascia up to level $\mathrm{L} 5-\mathrm{S} 1 .{ }^{14}$ Acute bout of stretching of the lower limbs increases the maximal range of motion of the distant upper limbs and vice versa. ${ }^{18}$ Recen甲 studies indicate that tightness of the gastrocnemius and hamstrings are assoc4ated with plantar fasciitis. ${ }^{39}$ Since most skeletal muscles of the human body are dire? 4 ly linked by connective tissue, symptoms may develop in areas distant from the pointtaf dysfunction. ${ }^{40}$

Accepance of the concept that a fascial tensegrity system connects the whole body is natmecessary for a scientific discussion of tension spreading to other areas of mus $24 \overline{6}$ groups or structures. Some studies indicate that a tensegrity model might not 
be atwae representation of the whole fasciomusculoskeletal system, and some evidetice supports tensional propagation only to certain areas. ${ }^{41}$

\section{Myerascial Pain Syndrome}

Theragre several phenomena that accompany MPS including: trigger points (TrPs), actirsdoci, taut bands, satellites, and the local twitch response.

Triggatr points - Changes in fascia are associated with pain in TrPs and tender spots. Mar25 patients with active (ie, painful) TrPs have other areas with the same eleçв̈physiologic findings that are not symptomatic, called latent TrPs. Latent TrPs seer5to only cause pain upon palpation, while active TrPs cause pain and symptoms botla 58 the site palpated and referred elsewhere..$^{2,49}$ The arising of pain is attributed to th56e palpable areas in the connective tissue, which seem to activate nockeseption. ${ }^{2,4}$

TheOskes of the origin of TrPs emphasize the chronic contraction associated with ther $250 \mathrm{r}$ their tendency of appearing at the muscle spindle. ${ }^{2,9}$ Others suggest TrPs repressent hyperactive end-plate regions. ${ }^{7}$ More theories that either deny the exiszence of MPS or believe it represents a focal dystonia, microtrauma, or are of centrid nervous system origin, are also hypothesized. ${ }^{2,7}$ Critics of MPS argue that the findDrgs seen at TrPs are simply variants of a normal physiologic finding. ${ }^{7}$ There is reaser4 to suspect this is true: about $50 \%$ of adults have active or latent $\mathrm{TrPs}^{2,9}$ and infaD65 have been observed with point tenderness of the rectus abdominis muscle and radic. These both were relieved by sweeping a stream of vapocoolant, which inacik7ates myofascial TrPs, over the muscle. ${ }^{5}$ 
TrPs68e extremely common. Among 224 non-specific neck pain patients, TrPs were four $\$ 9$ all of them. ${ }^{9}$ In studies in pain clinics, $74-85 \%$ of those presented to a clinic had $2 \pi \mathbb{P}$ s the primary cause of their pain. ${ }^{9}$ TrPs are one of the most frequent causes of neck pain and back pain. ${ }^{42}$ The severity of symptoms caused by TrPs ranges from the $\mathbf{z} \not \mathbf{b}$ nizing, incapacitating pain caused by extremely active TrPs to the painless restziczion of movement and distorted posture caused by latent $\mathrm{TrPs} .{ }^{5}$ The influence of latent TrPs on physical function is commonly overlooked. ${ }^{5}$ Patients who had other kind575f severe pain, such as that caused by a heart attack, broken bones, or renal colie,75ay that the myofascial pain can be just as severe. ${ }^{5}$ Some suggest $\operatorname{TrPs}$ are presempt in up to $85 \%$ of individuals with colorectal, urological and gynecological pelvadeain syndromes, and can be responsible for many of the symptoms related to thesegyndromes. ${ }^{43}$ It was suggested that TrPs or myofascial tension, not exerted by extergcal forces, can apply enough force to cause various abnormalities, including compression and entrapment of anatomical structures, ${ }^{44}$ decrease joint range of movernent, ${ }^{7,16}$ influence viscera, ${ }^{9,45,46}$ lead to musculoskeletal abnormalities, ${ }^{47}$ and alter\$3ood and lymph flow. ${ }^{48}$

Acti\&4oci - TrPs show electrical abnormalities called 'active loci'. This is a small regids5in a muscle that exhibits spontaneous electrical activity (SEA), often charerized as endplate noise measured on electromyography (EMG), leading to chr@8ic contractions. ${ }^{9}$ Although some literature does not regard TrPs as a disc288inating factor for MPS, the 'Active Locus' seems to be a consensus. ${ }^{7}$ 
Tau民nd - A taut band is thought to be composed of several TrPs and shows excove endplate potential activity. ${ }^{9}$ Sustained abnormal activation of acetylcholine (Acl2)ibis hypothesized to create an "Energy Crisis" component. ${ }^{9}$

TrP \$qzellite - TrP satellites are another disputed aspect of MPS. Some literature stat293TrPs themselves can induce motor activity (referred spasm) in other mus294s. ${ }^{49}$ Illustrated by an example where pressure on a TrP in the right soleus mus 295 induced a strong spasm response in the right lumbar paraspinal muscles. Pressagre applied to a TrP in the long head of the triceps brachii muscle indued a strolg7motor unit response in the upper trapezius muscle only during the 20 seconds that2pressure was being applied. This response failed to be reproduced following inacroation of the triceps TrP. It is known as a 'satellite' phenomenon. ${ }^{9,49}$ Moreover, it seans TrPs can spread, since an active TrP in one muscle can induce an active satestote $\operatorname{Tr} P$ in another muscle., 99

Varizoss hypotheses have been suggested to explain the mechanism of MPS, among the 308 re trigger points, non-muscular sensitization of the nervi nervorum, central nerBO4s system, and several other theories..$^{2,7,9,50}$ Some relate the muscle conberctions in TrPs to a myotatic (stretch) reflex evoked by fascial tension. ${ }^{7,9}$

\section{Myeofibroblasts}

Fascantself is able to actively contract. Tensional alterations are caused by conbrestile cells. ${ }^{51}$ Myofibroblasts are present in some developing or normal adult tiss 399 , altering tissue tension. ${ }^{30,51}$ Although most tissues exist under a mechanical tensim, the same is not necessarily true of their resident cells; These are protected 
fron the relatively massive external loads by the mechanical properties of the surrmending matrix. ${ }^{51}$ In engineering terms, this is called 'stress-shielding', occurring duestosthe matrix material that they deposit and remodel. ${ }^{51}$

Norß1zl fibroblasts are highly sensitive to the physical stimuli. Tomasek et al. show cert3it5 changes in tissue rigidity, strain, and shear forces are mechanical cues sensed by fitaroblasts that lead them to trans-differentiate into another cell phenotype. ${ }^{51,52}$ In osher words, the transition from fibroblasts to myofibroblasts is influenced by mechilanical stress. If subjected to mechanical tension, fibroblasts will differentiate into3peoto-myofibroblasts, which contain cytoplasmic actin stress fibres that ternaroate in fibronexus adhesion complexes. ${ }^{51,52}$ The adhesion complex bridges the myof 2 broblast's internal cytoskeleton and integrins with the ECM fibronectin fibrils. This3enables proto/myofibroblasts to generate contractile force in the nearby ECM by tBastion. The force inside the ECM is maintained over time and reinforced further by ratedeling and collagen deposition. ${ }^{51}$ Functionally, this provides a mechanotran32l5uction system, so that the force that is generated can be transmitted to the surroutnding ECM. ${ }^{51}$ Increased expression of alpha smooth muscle actin ( $\alpha$-SMA) is direzl|x/ correlated with increased force generation by myofibroblasts in a positive feed $\$$ ck regulation. ${ }^{51}$ A vicious cycle is suggested, in which tension facilitates TGF$\beta 1$ s\$ggaling, which induces $\alpha$-SMA expression. In turn, this increases development of moreztension, which upregulates TGF- $\beta$ and $\alpha$-SMA repeatedly. ${ }^{51}$ In short, myofabroblasts generate the mechanical conditions that enhance their contractility in a trimental loop. ${ }^{51}$ In contrast to the reversible short-lived contraction of striateat and smooth muscles, myofibroblast contractility is different: with ECM 
synthessis and degradation (ie, remodeling) they lead to irreversible and long conbroctures in a process that can be maintained for long periods of time. ${ }^{51}$ It is thouglet that myofibroblasts use a lockstep or 'slip and ratchet' mechanism, in increBrental and cyclic contractile events using Rho-kinase system, and aside the myossa light chain kinase (MLCK) system. ${ }^{51}$ Once achieved, contracture shortening does390t require the continuing action of myofibroblasts. ${ }^{51}$ The visible appearance of conthus tension in pathological contractures is the consequence of contraction and3๕modeling. ${ }^{51}$ Myofibroblasts might transmit considerably high forces. ${ }^{51}$

It is $\$ 80$ possible that myofibroblasts can couple their activity directly to other cells like 3 A 9 ocytes via gap junctions and act as a unite. ${ }^{51,53}$ Interestingly, if the collagen lattis\&4is released from its points of attachment such that stress in the matrix is lost, the Bells rapidly undergo isotonic contraction and subsequently lose their stress fibrßstand fibronexus adhesion complexes. ${ }^{51}$

\section{Treatments for MPS}

Seve pharmacological and non-pharmacological treatments are suggested in liter349re.

Nonß§harmacological: $:^{4,9,11,54-57}$ including manipulative therapy, vibration therapy, exeBcsse, etc. Since it is shown that needle insertion reduces pain and SEA on EMG, ${ }^{58}$ this 354 ggests a therapeutic role for mechanical needling.

PhaB5ß3acological: ${ }^{4,9-11,54}$ including non-steroidal anti-inflammatory drugs, opioids, topis54 creams, and TrP injections. 


\section{Discussion}

Theffirst part of the discussion analyzes MPS, and the second part focuses on fibros̄yyalgia.

\section{Parts - A theoretical model for MPS}

Synthosis of the data gathered in this review leads the author to the following anaßßsos and suggested mechanism:

\section{Etiobrgical considerations:}

TheB@zare three aspects of fascial induced pain to consider, from the standpoints of physires, biomechanics, and cellular biology. These seem relevant to fascial tension, TrPsigand MPS.

The $3 f 5 n d p o i n t$ of physics relates to energy. Thermodynamically, the human body

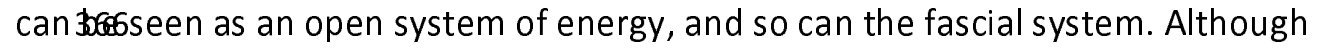
eneß@y and entropy are modulated by various factors, by nature, entropy of this systar will spontaneously tend to increase. To tense the fascia energy needs to be expsagled. Once fascia is tense the energy can remain as potential elastic energy or chäge due to other modifications, for example molecular rearrangement. HA has a moledular structure that enables it to have a high degree of entropy, like an entropic "sp \&rge". When entropy increases it generates osmotic pressure and diffusion of fluidss and other processes. Thus, when entropy of HA increases, osmotic pressure increzses, and stress decays. If stimulus is not removed after this acute stressing, 
fasc $\mathbf{B} \mathbf{z} \mathbf{w i l l}$ remain in the failure part of the stress relaxation curve and will be rembiteled in this state. Although entropy goes together with osmosis and stress decą,7each oscillation between different energy states will likely cause a loss of eneBģ being a non-ideal system, for example due to friction. Fascia has hysteresis and $3 \mp 9$ not a perfect "energetic spring" to oscillate between high-tension and lowtensiom states, ie, it dissipates energy.

Seco8dly, from a biomechanical standpoint the review shows that (i) simple stress decåzand recovery from it is a reversible process due to elasticity of fascia; (ii) trigg8Bpoints (TrPs) and myofibroblasts are found in normal individuals; TrPs are seeßs\&yen in childhood and infancy, and in animals. ${ }^{58}$ (iii) fascia continuously remb8tels itself and $\mathrm{HA}$ is continuously synthesized and excreted, (iv) a sedentary

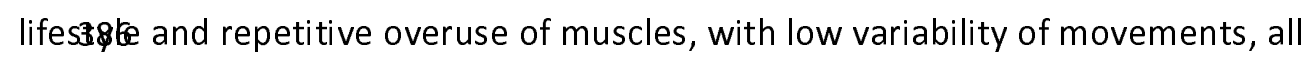
leadB8ठ fascial changes/fibrosis and possibly MPS; (v) exercise and proper movement relie 888 and prevent MPS; (vi) MPS seems to recur unless appropriate exercises are pressogbed.

Thesecuggest an underlying ongoing interplay between movement and sedentarism. Sinc 39 tensional changes are reversible in fascia of normal individuals and depend on the B९echanical state of the human body, this indicates fascia is meant to withstand and3903ntinuously undergo dynamic changes according to varying dynamic meçanical states. Since immobility often leads to collagen alterations, HA changes, myofft5roblasts, and pain, we can see MPS as a natural consequence of the sedentary lifesł9te. Resulting from the evolutionary "price" biology paid in a trade-off with cheagstry when trying to "come up" with a tissue as effective, pliable, compliant and 
stroßgas the fascia. This "bargain" served us well to function effectively as an orga98m dominated by continuous movement. It seems that by living sedentarily, the disadvantages of the properties of fascia (chondrifying, HA aggregation, failumito decay, and fibrosis) manifest pathologically. Stiffness and lack of mobility of fasctimas implications beyond a patient being unable to move adequately; it can affe 40 3he behavior of all cells interacting with the connective tissue matrix. ${ }^{16}$ If indet nature designed a way to relax fascia during movements and reverse these changss it might happen through (i) dissipation of fascial energy as mentioned aboße6(ii) mechanical effect of movement that ruptures fascial fibers or shakes off fibeAQ, which might explain why studies find extra-corporeal shock wave therapy to be effosctive for MPS (eg, Uritis et al. $)^{54}$; (iii) friction between sliding layers of fascia elevang the local tissue temperature, or "warming up" myofascial tissue. Literature suggasts the three-dimensional supramolecular assembly of HA breaks down proginelssively at $35-40$ degrees celcius. ${ }^{29}$ The more viscous is $\mathrm{HA}$, the more friction will to counter viscosity; (iv) increasing clearance of HA due to increased lymph flow113igher concentrations of HA lead to its more gel-like state, affecting the propenties of the matrix. (v) pandiculation; (vi) self-aware "palpation" as a part of one'sk15festyle.

The 4 hthrd aspect to consider is a cellular one: induction of myofibroblast by tension and4bly sedentarism. ${ }^{33,51}$ Chronic tension is exacerbated with more tension generated by $m \$ 8$ fibroblast smooth muscle actin fiber contractions. This makes it increasingly more1difficult to maintain a relaxation. Tension is converted to HA aggregation and entrozoy so long as compensation along the stress relaxation curve can allow for it. 
Increż\$e in HA concentration is expected to keep HA in the denser gel-like state, ${ }^{29,59}$ whiøbzwould plausibly be perceived by the individual as bodily stiffness. If the values of tansion reached at the stress relaxation curve plateau tend be above the value of the 仼neshold for myofibroblast differentiation, it will be a major driver for MPS (valu25 may vary between individuals). Biologically, the reinforcing of fascial cells withactin fibers may be the way of the body to express support of the repetitive mustantar effort. Accumulation of many foci of stretching along a sensory or symetic nerve, due to extracellular fibers pulled from multiple directions by prota 2 myofibroblasts, might cause peripheral nerves to be hyperirritable chronically. This4Bray explain why a study finds the number of active and latent TrPs is signiß@đantly and negatively associated with pressure pain thresholds (Do et al. $)^{12}$. A chrarsix peripheral pain could contribute to a central sensitization and to changes in spinm3zord pathways, though, as stated, the central mechanisms are not the focus of this 4 (1) These three dimensions seem to be relevant to fascial tension, TrPs and the $\$ 350$ logy of MPS.

\section{Patk46hysiological considerations}

Threfelements combined might help explain MPS. These are: (i) Tensegrity, (ii) TrPs, and4(3is) Stress shielding.

Mardisestation of MPS is seen in TrPs. Latent TrPs may be points that have previously nocieceptively sensed tension (ie, active TrPs), for example, microscopic tension due to s\&dentary behavior or a 'satellite', and then were mechanically induced to stress shietzhemselves via myofibroblasts. The stress shielding does not necessarily 
elimanate tension (and pain) completely, thus preserving some mechanical drive for furth\&4 proto/myofibroblast activity. Moreover, new myofibroblasts generate alpha smobatth muscle actin ( $\alpha$-SMA) and contractions themselves. ${ }^{51}$ Over time, especially if mechical stimuli continue, fascia remains more towards the failure part of the rela*ition curve, and cells have time for more stress shielding and matrix remeling. Then, latent TrPs (via myofibroblasts) start to exert their own tension. ThisAnforces the abnormality. However, that tension would be more diffuse as it spreseds along an intricate web of fibers (ie, stress shield), inducing more tensions, mor\$5fiorce gradients in fascia, more foci of stretch or entrapments of nerves, and othe15painful TrPs further away. If mechanical tension is sufficiently reduced by shie4\$Bg or by other means, myofibroblast will dedifferentiate or undergo apo $\$ \oplus \Theta s i s,{ }^{51}$ leaving behind a remodeled dysfunctional fascia. Multiple iterations of the 45 ntractile cycle result in incremental and irreversible tissue contracture. ${ }^{60} \mathrm{TrPs}$ app $\mathbf{\$ 6}$ on ultrasound as focal, hypoechoic regions and with reduced vibration amplistude, indicating increased stiffness. ${ }^{12}$

Thes\&lynamics may be the basis for the unexplained "metastasis" of TrPs and sate4bEes that Quinter et al. (2015) ${ }^{7}$ refer to. When sedentary behavior continues, it feedssenore tension down the cascade. The clinical manifestation would be deterforined not only by the amount of myofibroblasts, but by the inte46annectedness of their adhesion complexes, gap junctions, and fiber-cellular netA $₫ \mathrm{ks}$ as well. Studies suggest myo/fibroblasts form an extensive cellular network and 45 exhibit coordinated calcium oscillations and actively respond to mechanical stima $65^{61-63}$ Studies suggest myo/fibroblasts have stretch activated calcium channels, 
and intracellular calcium and myofibroblast contractility is mechanistically link $\Theta^{-60,61}$ Langevin et al. find evidence that leads them to a conclusion that soft tiss 46 \&ibroblasts form an extensively interconnected cellular network, suggesting the 469 ay have important and so far unsuspected integrative functions at the level of the wiole body. ${ }^{6}$

Actiłżzing a latent TrP is hypothesized to involve interference with the stress shield or stretch-activating myofibroblasts to rapidly contract, thus exposing the area to higher3tension and initiate nociception. Eliminating a TrP seems to induce a local twitthresponse, which possibly signifies the neuron or muscle's calcium driven resphthsse to a recovery from an active locus or shielded tension. Alternatively, it may be orfoff "flickering" of the myotatic reflex due to nearby myofibroblast rapid MLCK contraxtions and their waves of calcium flux. Active loci may be a multifactorial phemenon. For example, stress shielding (with or without gap junctions) sup\& $\bar{x}$ inposed on sympathetic activity, ie, a myotatic reflex on top of sympathetic drivÆ80t would seem plausible to expect one to "learn to relax" or "learn to cogatively override the sympathetic aspect by focusing attention", but not to willfygly override a reflex response. The fact that muscle spindles are surrounded by a capsile of connective tissue, an area that sometimes might be palpated as a nodat (ie, TrP) suggests that if there are microscopic tensions, they might possess a sensfisisity to generate more tension at the spindle (via proto/myofibroblasts), thus lock48g the stretch reflex to a certain degree. Locking the reflex would "turn on" an actiocus in the associated muscle. To complicate the above, if electrical coupling of this8structure occurs with an endplate (or non-intrafuseal fibers), via 
myof\&loblasts, it might perpetuate an "arrhythmic" picture on EMG, with backgoound noise, and random spikes upon myofibroblast contractions. Mechanical disraption of this structure eg, manipulative therapy, should unlock this pathology, at lest partially. This might be one of the reasons for different degrees of body rela*abion and the inability of some to experience it.

Not thstanding, other factors are not excluded. Factors associated with the central nerAOts system could also be implicated in the genesis of MPS, as well as genetics, envirmental factors, psychosocial aspects, chronic sympathetic "freeze" reaction to expryday psychological stress, etc. Based on this discussion, we might expect fact $\$ 8$ affecting fascial myofibroblasts to have potential to cause tension, pain, or evengead to MPS. For example, diet is believed to play a role in MPS, ${ }^{9}$ and studies suggest myofibroblasts are promoted by certain diets and by pestroides/herbicides. ${ }^{64-67}$ Similarly, the molecule CCN2/CTGF is suggested to play a role5102development of pain due to overuse, ${ }^{68}$ and CCN2/CTGF is shown to be impБ0Bant in myofibroblast $\alpha$-SMA synthesis. ${ }^{69}$ Applying this sort of logic, we may find50mre factors linking myofibroblasts to myofascial pain. ${ }^{70-73}$

It is $505 c$ lear where the tipping point between a status quo of movement-sedentarism and506eranged myofibroblast activity is. It is likely multifactorial, but lifestyle seems to boa major factor. A mechanical stimulus causes differentiation to myoffoldroblast, ${ }^{51,74}$ some studies suggest a threshold of $\sim 20-24 \mathrm{kPa}^{75}$ Therefore, mectomical forces might be one of other possible factors contributing to MPS and myofflibroblast induction. For example: sedentarism and muscle overuse, ${ }^{3,9,76-78}$ infe巨tion or inflammation, ${ }^{4,7}$ and trauma/fracture or immobilizing a casted 
$\operatorname{limb} \$^{4}, 2,74,79,80$ Since MPS is so prevalent, also common overlooked factors in a lifesfyke that is not evolution-oriented may be suspected, eg, medications that are shownto both induce myofibroblasts and increase risk of myofascial pain. ${ }^{72,73}$

\section{Sympattomatologic considerations}

TrPsad myofascial pain, particularly when severe, can cause various symptoms that are bibz limited to the fascial-muscular-skeletal system. It is suggested that the sympeshetic nervous system (SNS) causes TrPs. ${ }^{4}$ Reciprocally, pain and TrPs can acti\&aÆe the SNS., ${ }^{2,4}$ This activation may actually be due to coactivation of larger dianמשer mechano-sensitive afferents rather than nociceptive afferents. ${ }^{81,82}$ If the SNS581activated by paraspinal mechanical stimuli, then maybe it can be activated by mussadar tension alone. If so, this may serve as a slippery slope for further TrPs, actisejoci and MPS. Moreover, it seems that when MPS is severe, a widespread pat\$akgy may manifest like a fasciomuscular armor under the skin (ie, "fascial arm5xing"). For example, immunohistochemical examination of sampled fascia from low $5026 c k$ pain patients demonstrates a myofibroblast density comparable to that four 1 in "frozen shoulders". ${ }^{14}$

Peopł with MPS fail to relax muscles due to a mechanical reason; Myofibroblasts can 58 \&thesize $\alpha$-SMA fibers, which would transform fascia into a pseudo-muscular confiactile tissue. It is not necessarily innervated and can remain contracted for yeaEss $1^{1,83}$ Since this tension is not innervated by voluntary control, and despite invoßsement of the SNS, seeing these patients as people who just "need to relax" as firsthlisie management is counterproductive. Failure to address the mechanical aspect 
of nosfascial pain is expected to lead to a detrimental cycle of pain and over medis Notborthy, if the pain in "non-specific low back pain", for example, arises due to a fasc5\$7pathology, then calling it "non-specific" could be misleading.

Fina $\$ \beta, 8$ sedentary behavior and active lifestyle are widely emphasized in public heaktio However, much focus is dedicated to cardiovascular and metabolic aspects. This5keview sheds light on the link between lifestyle and pain and suffering. It is wor5h noting that the most common recommended treatment of MPS found in this liter54are review is mechanical, including needle insertion, movement (passive or acti\$\&,3breathwork and vibration), and massage/manipulative therapy. It helps treat MPS reduce fascial related pain..$^{2,3,4,9,11,43,54-57}$

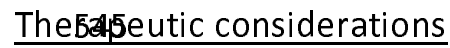

Nee5/ing was found as a recurrent modality in literature. Needle treatment of TrPs

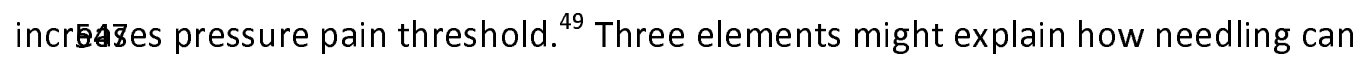
help 5 at MPS; These are (I) tensegrity mindset (II) trigger points and satellites (III) mycoffll|groblast generated tension and stress shielding.

Sinc50eedle insertion itself seems to relieve pain, ${ }^{87}$ this may indicate needling creatses a focus for a mechanical tearing action on the fascia. Meaning, the tension and5słæear stress inside fascia would pull on the weak point of fine needle insertion ove55Bme, until the sum force vectors, or horizontal components, at that point is elimbited or needle is removed. Cutting off tension and fascial fibers is expected to causerells to rapidly contract, and subsequently lose their stress fibres and adhesion 
compstexes. ${ }^{51}$ If proto/myo/fibroblasts are present (as a node or a line), tearing fascia woulshaffect the tensegrity structure. Mechanical stimuli can induce myofibroblasts stre $\$ 58$ activated calcium channels, and calcium is coupled to contraction in these cells59961 After calcium influx, MLCK activity might lead to increased contractile forcsoand tension acutely, if they do not lose their stress fibres and adhesion compes. If needles tear the fibers, tension will decrease. Studies observe increase or dease in contractility and stiffness, and witness needle grasp upon mechanical stimE $6 \mathrm{~B}^{88-91}$ Myo/fibroblasts create tension in the attached matrix, and upon release

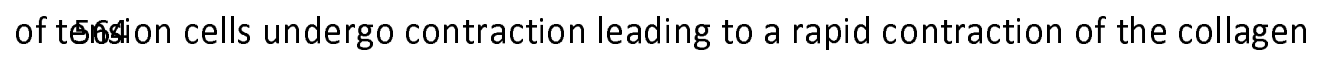
mat $565^{51}$ So, it may be that any "damage" by the needle actually allows for cutting off satejtates. Mechanically inducing changes, ${ }^{88,91}$ and allowing for the returning of fascia to its 98 lace. If inserted deep enough, it might also free edematous fluid, $\mathrm{HA}$, or other fact569 trapped within the layers (eg, serotonin). ${ }^{12,92,93}$ This would gently change the dynañics of the structure and the entropy (hidden tension) of the system. Upon compplete freeing of tension cells undergo apoptosis with reduction of $\alpha$-SMA. ${ }^{94}$ Studies indicate needling lowers myofascial stiffness as measured by shear wave elas\$ฮgraphy, ${ }^{95-97}$ suggesting a potential for a mechanical "re-alignment" of the fasc58musculoskeletal system and actual tensional release.

The $5 n$ re stress-shielding is present at the locus of insertion, the longer it should take $5 \oplus r$ relief to happen. Stretch lesions along sensory nerves should be relieved too 57 7 is treatment acts like breaking the connections in a geodesic dome of the tensegrity model and then allowing for new healthier connections to form by natural 
remøzeling. (The following video observations may help grasp this model) 98-101 $^{9}$ Elimb8ating one node is not enough in this framework, on the contrary: if done impsepperly, it can only add tensions to other nodes in the structure and exacerbate the Egeneral pathology. Starting the relaxation process away from the focus of pain makesssense in this framework. It slowly and progressively begins to relax the prin58 4 , secondary, tertiary etc. nodes in the satellite network, approaching the highesst area of unshielded tension later and collapsing the tension in a concentric way5\&6ccording to the biotensegrity model, the peripheries carry tension affecting the 58 cus and are equally important. Li et al. state that currently available needle delif88y systems deform and move soft tissue and organs. ${ }^{102}$ This may suggest that insersigng a needle causes windup of connective tissue and modulation of the fascial net based on internal forces. Alignment of the system should be done properly. Thespuestion is: What is properly? What is proper needling? Where, in which order, dep5lgzand time, is best for which symptom? Studies suggest needling affects facia at the of insertion and at a distance. ${ }^{91,103-105}$ How fast should the fascia be relesged? Indeed, it would be beneficial if we could monitor the mechanical state of fasc $\$ \$$ y palpation. By releasing the tension properly, the tissues can return to their healay alignment without other areas exerting pulling forces. Following the "dar598ge" of needling, the fascia will regenerate via myo/fibroblasts matching the bio-\$98chanical state. Evidence suggests that fascia regenerates within app508imately 3-24 months after fasciectomy/fasciotomy. ${ }^{106,107}$ It is unlikely that tearfog the fascia (if done properly) will seriously compromise physiology as this woudd1have manifested as a complication after every invasive surgical operation. New6œxtracellular fiber deposition will be based on optimized structural 
conformation. ${ }^{22}$ Some may say inserting several needles subcutaneously sounds like a surgitcal intervention of the fascia. A gross illustration of this framework can be fou 15 the supplementary material (Figure 2).

Exares of these principles may have transpired in several studies. Three findings are boiffly presented as follows. A study of 37 patients who were all diagnosed with plaras fasciitis and all had been treated with corticosteroid injection into the calcao®al origin of the fascia. ${ }^{108}$ All had a presumptive diagnosis of plantar fascia ruptaine. 30\% described a sudden tearing in the heel, while the rest had a gradual chafge in symptoms. Most of the patients had relief of the original heel pain, but it haddaeen replaced by a variety of new problems, including dorsal and lateral midfoot pair615swelling, foot weakness, metatarsal pain, and even metatarsal fracture. ${ }^{108}$ Symfottoms tended to localize to the dorsal side of the foot. ${ }^{108}$ In all 37 patients there was6apalpable diminution and footprints showing flattening of involved arch, and MRI6sløowed fascial attenuation. ${ }^{108}$ The study's author concluded that plantar fascia ruptaire had occurred. The majority had resolution of the new symptoms within 12 morftiss. In the rest, symptoms remained. ${ }^{108}$

A second study encountered the same enigma: $68 \%$ of patients with plantar fasciitis had 620 udden rupture associated with a corticosteroid injection. Although it relieved the original pain, these patients developed new problems: arch or midfoot strain, late6212plantar nerve dysfunction, hammertoe deformity, and stress fracture. ${ }^{47}$

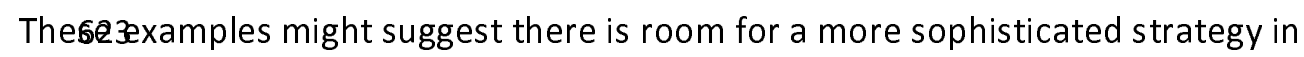
treandy the fascia instead of simply aiming and firing at the pain. Maybe this should 
be i62Grpreted not as an adverse event, but as a testimony that the treatment moda2/fty undermines the tensegrity system. Conceivably, behind this is a release of fasc 62 in an area of very high tension, causing too drastic of a change in the tensegrity structure, instead of approaching this tension gradually. A sudden change migkz $\mathrm{ghift}$ the forces to other areas and exacerbate the imbalances, ${ }^{109}$ perhaps sufficsent to cause bone fracture. The mechanism by which those complications resofied over a period of 12 months is expected to happen via ECM remodeling and stre63shielding that area from tensegrity tension. Moreover, it was found that ster@8 injection decreases fibromatosis, fibrosis, and myofibroblasts in adhesive cap\$314tis, ${ }^{110}$ suggesting injection to the plantar fascia has potential to affect myoffłşroblast generated tensegrity forces.

The 6 thrd finding that might be interpreted under these principles, is the phenomena of: "fBllowing a tooth extraction, a pain behind the ear and on the side of the face in the $6 \mathbf{3} \%$ or so prior to facial weakness often constitute the earliest symptom of Bell's palsø83' $9^{3}$ (Kasper et al. 2018, p222-223). Guided with a tensegrity mindset, this may sugfost a relationship in the "geodesic" face: a pain develops behind the ear possibly as a6'reciprocal" point for tension in the jaw, which happens to be near the emefrgence of the facial and trigeminal nerves from the skull. This is a reasonably suscertible area with curved bones to serve as a focus for tension. Of course, it does not thessarily mean that releasing tension from around the mastoid process is the key $₫ \oplus 5$ preventing the complication. Tensegrity domes are made of many nodes, and "to 6hange a node is to change the dome". Therefore, pain behind the ear is first and foreäst an indication of extreme tension, and only then pain. A tension like every 
oth $\$$ myofascial tension, eg, plantar fasciitis. However, this pain is located at a derictome of a cervical root, which is a distant nerve and is unlikely to be directly inju6s by tooth extraction. A sudden intervention in the face probably emulates the same5action as a calcaneal injection. If high tension is present (for example a temproromandibular tension seen in up to $25 \%$ of the population $)^{2}$ it will have the samespotential energy to damage structures in the face, as implied by a metatarsal fractofine. In the face it seems to cause a palsy of a nerve, like the foot in plantar fasctistss, as discussed above. The degree of damage is modulated by the degree of the energy. ${ }^{109}$ If correct, this means two possibilities present themselves: eithes $\pi$ his palsy is not a Bell's palsy, or a Bell's palsy is not idiopathic. In any case, it hightgghts the instrumental importance of gentle and progressive release of fascia in a promer way. Therefore, "not feeling much" may be a good thing when needling fascbioln fact, we can predict sometimes pain might worsen at first, reflecting a nonideæ6modulation of force vectors. Less pain during treatment can also lead to more comfdeance from patients. Research has yet to establish empirically if fascial release prio6e@ (or even after) tooth extraction, can affect the rates of this palsy.

Mo\$6kation of tensegrity vectors may be a factor in reported cases where (i) trea6̧ळent of Dupuytren's disease leads to Boutonniere deformity, ${ }^{111}$ (ii) carpal tun 6 66release increases risk of trigger finger; ${ }^{112,113}$ (iii) treating the elbow for tennis elbo\&itrequires a supposedly unrelated shoulder arthroscopic decompression, ${ }^{114}$ (iv) sim6k8neous bilateral digital flexor rupture occur; ${ }^{115}$ or $(v)$ spine surgery leads to comfortment syndrome of the foot. ${ }^{116}$ It seems plausible since fascia is a system.

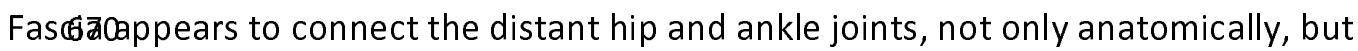
also6inechanically, supporting the concept of myofascial connectivity. ${ }^{18}$ Most skeletal 
musctes of the human body are directly linked by connective tissue. ${ }^{40}$ Acute bout of strefzling of the lower limbs increases the maximal range of motion of the distant upp $₫ \mathbf{T}$ 4imbs and vice versa. ${ }^{18}$ Fascia is continuous from the trunk across the upper and $₫ \overline{\varpi 5}$ ver limbs, ${ }^{18}$ and because of the direct morphologic relation of the hamstrings and $₫ \varpi \varpi v$ back region, relieving tension of the posterior thigh muscles could be a con $6 \notin$ ixable approach to alleviate back pain. ${ }^{117}$

In c $\boldsymbol{6} \overline{\mathbf{n}} \mathbf{8}$ lusion, under the framework of tensegrity, it might be logical to first needle the dorsal foot and foreleg in plantar fasciitis, for example, assuming connective tiss 680 s pulling the plantar fascia (ie, weak link in the tensegrity structure) and causigg pain. Therefore, aiming to primarily treat the underlying tensional abn68ßnality of fascia, and through this improving the symptoms of pain. Actually, it see 1033 TrP with severe localized pain may not be the source of pathological tension becøase myofibroblasts stress shield their area from tension: fascia is a living tissue that6pells rather than pushes. Treating only the painful point is expected to lead to

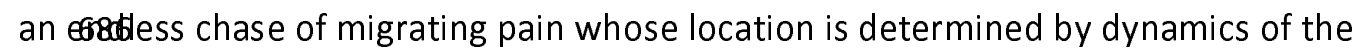
ten semity structure. Tension is likely to focus more near hard and angled surfaces that688ve sharp force-gradients; initially generating active TrPs (if a nerve is there to experience this) that have yet to sufficiently stress-shield themselves with a fiber web698y this rationale we may expect points to be concentrated more near areas of fasc 6 adjacent to solid or bony edges (spine, face, pelvis, chest, shoulders, knees, periøseum, perineurium, etc.). Tension will be present, ${ }^{118,119}$ but pain depends on the ${ }^{2}$ ree of sensory nerve involvement. ${ }^{120,121}$ This understanding may put MPS and fibr6ertyalgia on the spectrum of a common mechanism, whereby a more widespread 
pair6abid tenderness appears, at least in part, perhaps due to an 'archipelago' of stre69eshielded points and taut-bands that generate and mask extreme tension. If trueg 97 severe manifestation of this might be described by some as equivalent to a sort6@8 "mild to moderate chronic compartment-like syndrome of the whole body". Whirmamay explain why "MPS" can "develop" into "fibromyalgia", at least in a subset

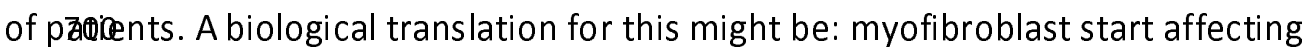
the confrazctile tissue, possibly with a reciprocal central sensitization. It was stated that dysfioßction of the posterior layer of thoracolumbar fascia has been reported as a chrorite compartment syndrome of the paraspinal muscles. ${ }^{26}$ These conclusions may be pras of the explanation to why these pain syndromes are epidemiologically so closed6associated with one another (as observed in population studies), ${ }^{122,123}$ why signifotant overlap is seen between various associated pain syndromes (reflecting anatorical overlap of involved fascia), why fibromyalgia tender points seem to

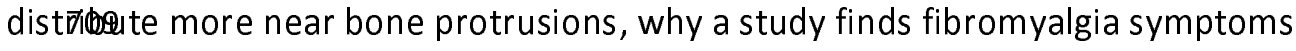
and Æ@uropathic pain correlate with tender point count (Amris et al. 2010) ${ }^{121}$, why imaging modalities fail to illustrate a clear familiar abnormality, why mechanically punđ̇aring their fascia recurs in literature as an empirical treatment option for them, and 7 Biby fibromyalgia manifests with extremely high intramuscular pressures and can bretaccidentally resolved by invasive surgery (as will be discussed below). It can also7ks non7sfevere chronic ischemia. Studies of fibromyalgia observe various organic abnøెrønalities, ${ }^{124-141}$ which might support this framework. To the best of the author's 
knowlge, no study is found to describe the manifestation of MPS when global and widespread.

\section{Park2 - Considering fibromyalgia as an entity involving}

\section{mechanical compression}

\section{$\underline{\text { Carđioovascular findings }}$}

Stưties show tissue stiffness is significantly increased around $\operatorname{TrPs},{ }^{142}$ and blood vesseds near TrPs have retrograde flow in diastole, indicating a highly resistive vasaplar bed. ${ }^{138}$ A global compression might explain a few findings that will be ment16ned here briefly. Various abnormalities in fibromyalgia suggest an underlying widespread organic pathology that impairs perfusion throughout the vascular syst巴28. Capillary microscopy studies of fibromyalgia show fewer capillaries in the nail fołd and significantly more capillary dilatations and irregular formations than the healtboy controls. ${ }^{128}$ The peripheral blood flow in fibromyalgia patients was much less $\pi$ timan in healthy controls. ${ }^{128}$ This suggests that functional disturbances are preser2t in fibromyalgia patients. ${ }^{128}$ While one study shows a decrease in tranżzapillary permeability in fibromyalgia patients, ${ }^{129}$ few studies find abnormalities in the 1 rterial system as well. ${ }^{143,144}$ However, studies of peripheral arteries in fibrð̄Byalgia are scarce. Findings from a study of biopsies of fibromyalgia cases with\$6t obvious muscle trauma indicate definite but nonspecific muscle changes whiฮblare suspected to be secondary to "chronic muscle spasm and ischemia of unk̄̄B̊nn etiology". ${ }^{124}$ 
Katza@ al. found intramuscular pressure measures substantially higher in the trapetous of patients with fibromyalgia with a mean value of $33.48 \mathrm{mmHg} .{ }^{145}$ Only 2 of 1081patients had muscle pressure of less than $23 \mathrm{mmHg}$. The mean pressure in rheưnzatic disease controls was $12 \cdot 23 \mathrm{mmHg}$. The burden of the pressure abnø̋日enality may help explain the diffuse muscle pain of fibromyalgia and may be an intrinß4c feature of fibromyalgia. ${ }^{145}$ Therefore, fibromyalgia as a disorder of excles 5 bvely central pain processing should be revisited. ${ }^{145}$ Substantially higher muscle presstfre aligns with an analogy of "a sort of mild to moderate global chronic complartment-like syndrome" which either compresses the muscles or distends the musct8 spindle, or both, and may explain why anxiolytics and muscle relaxants do not 7 rk very effectively with this entity. At the end of arterioles, mean pressure is app̄̄ळimately $30 \mathrm{mmHg}$, and then decreases further in capillaries and venules. ${ }^{146}$ Chrø̄̄ilic intramuscular pressure of $33.48 \pm 5.90 \mathrm{mmHg}$ might reflect some

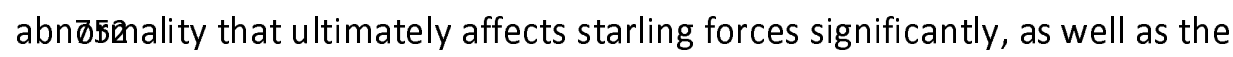
pres\$5ire gradient along arterioles, capillaries, and venules. The most widely used diagłFalstic criteria for diagnosing chronic exertional compartment syndrome (CECS) are 75 5se proposed by Pedowitz et al. for CECS of the legs, and include at least one of thøछfollowing intramuscular compartment pressure measurements: (i) preexercşe pressure $\geq 15 \mathrm{mmHg}$ (ii) 1 minute post-exercise pressure of $\geq 30 \mathrm{mmHg}$, or (iii) 858inute post-exercise pressure $\geq 20 \mathrm{mmHg}$. Therapeutically, reduction of mus $\$ 9$ pressure may change the clinical picture substantially in fibromyalgia. ${ }^{145}$ If myơf shoukt be reduced by releasing the fascia, according to the "fascial armoring" model, sinceiz is currently not a psychologically generated contraction. Shear wave speed of 
myơfascial latent TrPs and adjacent tissue in the infraspinatus is elevated compared to c $\overline{6} \mathbf{4}$ rol patients and is associated with increased muscle stiffness. ${ }^{142}$ A study of froz $\bar{E} \tilde{E} 5$ shoulder finds large numbers of capillaries and venules in the subsynovium of froz®ø্টshoulder samples compared with the controls. ${ }^{19}$ If fascial compression impđ̈đtes starling forces and causes low-grade ischemia in these conditions, it might be bऋ\$ogically expected that the body will secrete factors that increase total numpl6er of capillaries and venules, and factors that vasodilate veins (eg, nitric oxide). Suckzabiological response would lower total venule resistance via parallel resistance and $7 e$ ezestablish a pressure gradient in the vessels.

\section{Metäbolism related findings}

A miarodialysis study examined interstitial concentrations of metabolic substances in fibrø̄̄nlyalgia. ${ }^{147}$ Concentrations of lactate, glutamate, and pyruvate, were signౌffíantly higher in patients compared to controls. ${ }^{147}$ A study by Mclver et al. foumđahat during resting conditions, the ethanol outflow/inflow ratio (inversely rela践 to blood flow) increases in fibromyalgia patients over time compared to healthe/ controls $(\mathrm{P}<0.05) .{ }^{148}$ Fibromyalgia also exhibited a reduced nutritive blood flow/7Osponse to aerobic exercise $(P<0.05)$. There was an increase in dialysate

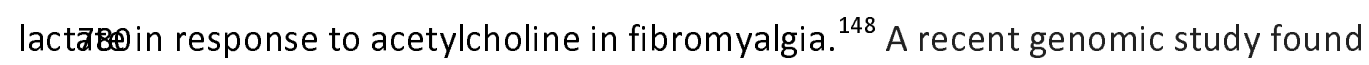
the $\$ 8$ sence of a $\mathrm{C}$ allele at the single nucleotide polymorphism of mitochondria $\mathrm{m} \cdot 2 \mathrm{B8} 2 \mathrm{2T}>\mathrm{C}$ significantly increases the risk for fibromyalgia (odds ratio $=4 \cdot 6) \cdot{ }^{149} \mathrm{It}$ was7 755 ociated with decreased mitochondrial membrane potential under conditions

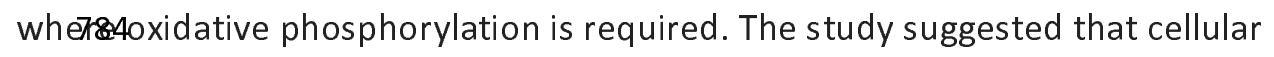
ene阺5 metabolism contributes to fibromyalgia and possibly other chronic pain 
conđ\$tons, indicating a role of oxidative phosphorylation in pathophysiology of chrođisic pain. ${ }^{149}$ A clinical trial found hyperbaric oxygen therapy can lead to signiseant amelioration of all fibromyalgia symptoms, with significant improvement in quety of life. ${ }^{150}$ Fibromyalgia has a hypomethylation DNA pattern, which is enried in genes implicated in stress response and DNA repair/free radical clearance. ${ }^{151}$ Such changes occurred parallel to changes in cortical excitability para192eters. ${ }^{151}$ From the first part of this scoping review, the link between fibr $\bar{\varnothing}$ Bßyalgia and oxidative stress, increased intramuscular pressure (that is higher than 24 three criteria for CECS by Pedowitz et al.), and reduced blood flow meażtrements, is self-explanatory.

\section{Stiffress, Pain, and the Spine}

Wađlgter et al. quantified muscle damping, which reflects muscle tension, in fibrøasyalgia patients and found all patients had increased muscle damping, some in bothyegs. ${ }^{131}$ Mean values were more than twice that of controls and maximum valumore than three-fold higher. ${ }^{131}$ The increased DNA fragmentation and ultr8otructural changes in muscles of fibromyalgia patients suggests it may be a resı80 of chronic contraction. ${ }^{125}$ Wachter et al. stated increased muscle tension is not mediäed by extrafusal muscle fibers and that the alpha and gamma motoneurons are involved in those contractions. ${ }^{131}$ They suggest stiffness or tension may be duestossympathetic activity, however, they state this explanation does not account for $\$ \mathbb{B}$ increased damping is seen more often in one leg rather than in both. ${ }^{131}$ As mersøøned, TrPs appear on ultrasound as focal hypoechoic regions and with reduced vibration amplitude on vibration sono-elastography, indicating increased tissue 
stiffess. ${ }^{138}$ A non-symmetrical tensegrity abnormality could account for why tension can\$mediated not by alpha or gamma motoneurons or extrafusal fibers, and at the 8 atme time unilateral.

Oth\&itbody structures are also involved, among them are nerves. Perez-Ruiz et al. findghizh rates of carpal tunnel syndrome in fibromyalgia. ${ }^{152}$ Why is a nerve compdression syndrome found to be more common in fibromyalgia, if it does not refl\&at5some compressive abnormality? (Fascio)musculoskeletal symptoms are repented often by patients: stiffness is one of the most common complaints. ${ }^{153,154} \mathrm{~A}$ survery of 2,596 fibromyalgia patients finds patients ranked the intensity of their pain low818han the intensity of morning stiffness. ${ }^{153}$ Considering central sensitization as a solermpechanism raises several questions: why is morning stiffness so commonly repseced among fibromyalgia patients, and even ranked higher than pain? Is it simply becsase of sensitivity, stress, and physical deconditioning? Does central sensitization occ8Ronly in certain sensory tracts like pressure, proprioception, and pain? There see $82 B$ be little to no reports of extreme sensations of vibration, for example. Is centat sensitization random or does it follow a pattern? Painful points seem to be distßibuted in the same topography among different individuals. However, if the loca\$zation of pain and hyperalgesia is not random, why can sensitivity appear in alm88 any area in the body? Why are these areas not correlated with the hon 828 culus? How does pain migrate? And what is special about the occiput, second $\cos 182$ chondral junctions, knee pad, and two centimeters distal to the lateral epicsordyle - points used to diagnose fibromyalgia (as described by Kasper et al. 20183 p2637) ${ }^{3}$ ? Sugawara et al. suggest mechanical compression of the dorsal root 
gangion (DRG) by a mechanical stimulus lowers the threshold needed to evoke a response and causes action potentials to be fired. ${ }^{155}$ Action potentials that may even per\$3tafter the removal of the stimulus and high mechanical sensitivity are sugsested by this (in vitro) study. More in vivo and in vitro studies suggest the same $36^{156-158}$ As mentioned, dysfunction of the thoracolumbar fascia has been des817bed as a chronic compartment syndrome of the paraspinal muscles. ${ }^{26}$ It is also plat833le that pulling would have a significant effect on the DRG.

Warget al. find a bidirectional association between fibromyalgia and gas $\$$ sophageal reflux disease (GERD). ${ }^{159}$ Trying to explain this without a medanical peripheral element seems difficult. How do current theories explain this bidiBAetional linkage? It is possible GERD carries a strong overlooked psychological comalanent, but maybe we should give fibromyalgia more mechanical credit. This enti\&4,4if it is what it seems, would probably affect gastroesophageal pressures and rela8ajions and mechanically compress the paraspinal and intervertebral fascia and its colftents eg, DRG and the sympathetic chain against a vertebral body. If comparression has a similar effect on the sympathetic ganglion/trunk as it does on the DRG, 4 is might add a component of sympathetic abnormalities. Some studies suggest menical pressure on the sympathetic trunk due to osteophytes can cause various abn8ิธEnalities. ${ }^{160}$ Studies suggest para-articular fibrosis in the spine can involve neu85hstructures and cause tethering and irritation of nerves. ${ }^{161} \mathrm{~A}$ compressive fact8sxan explain decreased pressure/pain thresholds and explain why they happen to b\&5strongly associated with autonomic abnormalities. It also implies these abn8ิ5nalities can be illusive and reversible in certain conditions, as will be discussed 
bel 845 By the same rationale we might expect higher incidence of obstructive rather thar 8 entral sleep apnea, even after correcting for body mass index.

\section{Cons5tering multiple theories}

Mo 8258 tudies indicate fibromyalgia may include easy bruising, ${ }^{154,162}$ hair-loss, ${ }^{154}$ red\$85d skin innervation, ${ }^{163}$ tingling, creeping or crawling sensations, ${ }^{164}$ reduced fect8 or infertility, ${ }^{165,166}$ urinary urgency, ${ }^{164}$ changes in bowel habits, ${ }^{3}$ decreased opti\&6disk perfusion, ${ }^{127}$ dry eyes, ${ }^{164}$ functional voice disorders (including muscle ten $\$ 60$ dysphonia), ${ }^{167}$ wheezing, ${ }^{154}$, seizures, ${ }^{154}$ impaired cognition, ${ }^{154}$ and Raynaud's phemenonon. ${ }^{168}$ Can central sensitization and neuroplastic pain circuits alone be the expation of all these manifestations? Do psychosocial theories or somatization exp these? No single theory seems to fully account for fibromyalgia. For example:

866 If it is sympathetic hyperactivity, why does it cause wheezing?

867 If it is sympathetic-parasympathetic dysregulation, why is muscle damping 868 found to be increased unilaterally more often than bilaterally, why is postural 869 hypotension not in the diagnostic criteria, and why is it strongly associated 870 with sicca but lacks reports of chronic sialorrhea?

871 If it is inflammatory or autoimmune, where are the standard inflammatory 872 markers, why is it so closely associated with irritable bowel syndrome of all 873 conditions, and why does it respond to tricyclic antidepressants? Moreover, 874 what underlies the close association of acquired immunodeficiency 875 syndrome, ${ }^{169}$ and why does a study find placebo has a better outcome than 876 steroids as a treatment for fibromyalgia? ${ }^{170}$ According to this framework, 877 systemic steroids are expected to indiscriminately modulate the tensegrity 
878 structure, somewhat arbitrarily leading to an exacerbation or relief. A low879 grade neuroinflammation might occur sub-clinically in fibromyalgia, but what 880 drives it? The full cytokine profile of MPS and fibroblasts is not covered in this 881 review, however, some studies suggest chronic myofascial pain is associated 882 with, or causes, elevation of cytokines and inflammatory mediators, 883 fibroblast growth factors, serum reactive oxygen species, and 884 neuroendocrine signaling. ${ }^{19,171-173}$ However, not all studies find the same. ${ }^{173}$ 885 Fibroblast from fibromyalgia patients show a differential expression in 886 proteins involved in the turnover of the ECM and oxidative metabolism that 887 could explain the inflammatory status of these patients. ${ }^{174}$

888 Central sensitization is the most accepted explanation. Why should exercise 889 (or movement) be the cornerstone of treatment? What could be the 890 mechanism behind "fibromyalgia flares" induced by weather change, ${ }^{153}$ if it is 891 not a whole-body thermodynamic intervention of the fascia? Balneotherapy 892 shows conflicting evidence as a treatment option. ${ }^{154}$ Is it possible there is 893 more to fibromyalgia than neurology and psychology? How is fibromyalgia 894 mechanistically different from "post COVID-19 syndrome" or "chronic 895 widespread pain syndromes"? What is the pathophysiological difference 896 between "primary fibromyalgia", "secondary fibromyalgia", and "juvenile 897 fibromyalgia"? In terms of "fascial armoring", there is no need to multiply 898 entities. How can central sensitization be measured reliably in cases where 899 not all myofascial pathologies have been excluded? Why should fibromyalgia, 900 as a disorder of central sensitization, be excluded from the differential 901 diagnosis if an individual has a "widespread pain index" of six and "symptom 
902 severity scale" score of eight? It seems to the author that the American 903 College of Rheumatology 2016 diagnostic criteria may not truly represent or 904 measure the underlying biological process, and that the cut-off chosen for 905 diagnosis might be biologically arbitrary. Isn't it often just a matter of time 906 until that individual has enough central sensitization/fascial armoring to be 907 diagnosed but with more impairment of quality of life, and is significantly 908 more difficult to rehabilitate? If central sensitization can be quantified, what 909 should be the treatment protocol when a "symptom severity scale" score 910 equals 1, if adopting a holistic view? Perhaps we should we give more 911 attention to prophylaxis of fibromyalgia? Reassurance and watchful waiting, 912 both, do not address the underlying problem. Fascial pathologies might be 913 easier to treat or prevent when detected early rather than late. According to 914 central sensitization, why prefer milnacipran, duloxetine, and pregabalin, but 915 not venlafaxine, tramadol, or gabapentin? Which diets are best, and which 916are worst for fibromyalgia based on central sensitization, theoretically? A 917 pharmacological or nutritional agent that induces myofibroblasts is expected 918 to be either ineffective or harmful in the long term in fibromyalgia. From the 919 standpoint of "fascial armoring", an antidepressant that induces 920 myofibroblasts might have a positive side effect: improved mood. 921 Why two centimeters distal to the lateral epicondyle but not halfway 922 between the elbow and wrist? Will surgery exacerbate central sensitization, 923 relieve it, or neither? More importantly, according to central sensitization, 924 why is Ehlers Danlos/hypermobility syndrome related to fibromyalgia? 
925 The pathogenesis of peripheral and/or central nervous system changes in 926 chronic widespread pain (CWP) is unclear, though, peripheral soft tissue 927 changes are implicated. ${ }^{175}$ Some evidence from interventions that attenuate 928 tonic peripheral nociceptive impulses in patients with CWP syndromes like 929 fibromyalgia suggest that overall fibromyalgia pain is dependent on 930 peripheral input. ${ }^{175}$ Allodynia and hyperalgesia can be improved or abolished 931 by removal of peripheral impulse input. ${ }^{175}$ Central disinhibition is also 932 hypothesized. However, this mechanism also depends on tonic impulse input, 933 even if only inadequately inhibited. ${ }^{175}$ Thus, a promising approach to 934 understanding CWP is to determine whether abnormal activity of receptors in 935 deep tissues is part of the manifestation and maintenance of this 936 condition. ${ }^{175}$

937 Perhaps the relationship between fibromyalgia and hypermobility syndrome 938 has to do with changes in ECM properties that induce myofibroblasts, thus 939 initiating a widespread MPS cascade? Studies of patients with Ehler940 Danlos/hypermobility syndrome find up to $80-100 \%$ have CWP and evidence 941supports a close association between hypermobility syndrome and 942 fibromyalgia. ${ }^{176,177}$ Of all associations with fibromyalgia, Ehlers943 Danlos/hypermobility syndrome is one of the closest, perhaps even closer 944 than depression. Why?

945Studies of hypermobility syndrome find cells express an increased transition 946 to the myofibroblast phenotype. ${ }^{178,179}$ A study suggests changes of collagen 947 microarchitecture regulate myofibroblast differentiation and fibrosis 948 independent of collagen quantity and bulk stiffness by locally modulating 
949 cellular mechanosignaling. ${ }^{180}$ The indistinguishable phenotype of 950 myofibroblasts identified in hypermobility spectrum disorders resembles an 951 inflammatory-like condition, which correlates well with the systemic 952 phenotype of patients. ${ }^{178}$ These findings suggest that these multisystemic 953 disorders might be part of a phenotypic continuum rather than representing 954 distinct clinical entities. ${ }^{178}$ According to this discussion, widespread induction 955 of myofibroblasts suggests a possibility for generalized peripheral pain 956 caused by generalized tension and compression. Under this framework, the 957 link between fibromyalgia and a variant of collagen is somewhat anticipated 958 based on fascial biology.

959Evidence for the input of psychosocial factors and stress in the pathogenesis 960 of fibromyalgia is suggested in studies. ${ }^{154}$ Cognitive behavioral therapy is 961 recommended in cancer pain, but we obviously do not conclude that cancers 962 are psychosomatic. So, if it is caused by stress and low mood or due to 963 childhood experiences of distress, how does it reduce skin innervation and 964 optic disc perfusion, and why selective serotonin reuptake inhibitors (SSRIs) 965 or anxiolytics are not the first line treatment? If abnormalities in cortisol 966levels can be enough to lead to such a clinical picture, why aren't they 967 enough to cause even mild hyperglycemia, neutrophilia, or osteopenia? 968 If cortisol, why is Cushing syndrome not usually portrayed with morning 969 stiffness and pain in 18 arbitrary points (arbitrary from a neurological point of 970 view) that are all adjacent to bone protrusions and are also adjacent to 971strong muscles and fascia (shoulder and trapezius, gluteus, thigh muscles, 972 pectoralis, muscles of mastication etc.)? Is there any clinical "fibromyalgia- 
973 ness" in either Adisson's disease or Cushing's disease, or in

974 Pheochromocytoma? Endocrine diseases involving these hormones are not

975 entirely free of emotional distress either.

976 Are the four conditions - fibromyalgia, irritable bowel syndrome, tension type

977 headache, and chronic fatigue syndrome - the same entity, or different from,

978 somatic symptom disorder? If the same, what is the pathophysiology of

979 somatic symptom disorder? If different, what is the mechanistic difference?

980 According to this model, they are the same, the difference being in the

981 network of myofibroblasts, degree of fascial tensegrity tension, layer, and

982 anatomical location.

983 Psycho-emotional explanations are a double bind for fibromyalgia: if muscle

984 tensions and contractions are psychologically induced by mental stress, how

985 are they maintained chronically with such high intramuscular pressures if

986 patients are often fatigued? On the other hand, if habitual psychological

987 muscle contraction is what leads to the fatigue, why can't they relax, and how

988 do muscles contract independent of alpha and gamma motoneurons and

989 extrafusal fibers? Would we not expect a combination of muscle relaxants

990 and meditation to be more efficacious? What kind of an entity can be both

991 systemic and unilateral or asymmetrical? A sympathetic theory does not

992 suffice, as stated by Wachter et al. and others. Figure $2 \mathrm{E}$ illustrates a possible

993 solution for a systemic yet seemingly "unilateral" pathology.

994 If fibromyalgia carries such a strong psychological component, why is it that a

995 study found an odds ratio of 2.53 and effect size of only 0.51 for anxiety

996 disorder in fibromyalgia, while for fasciitis and muscle spasms odds ratios of 
9975.27 and 6.05 , with an effect size of 0.92 and $0.99(p<0.0001)$, 998 respectively? ${ }^{181}$ Does fibromyalgia as a "functional somatic syndrome" 999 deserve some re-evaluation, and are we to dismiss these statistics as not 100由eing empirical clues? Why did a study find fasciitis to be one of the three 100 most associated conditions with fibromyalgia, while anxiety was not? ${ }^{181}$ Via 1008vhich mechanism does a neuroplastic pain cause so much muscle spasms but 100ßo abnormal Babinski sign, no clasp knife spasticity, no paralysis, and no 100 lonus, and why are spasms not as common in many other pain conditions? 100\$re these spasms driven by a mysterious psychoneurological pathology in the $100 \pitchfork$ rain that contracts muscles without using extrafusal fibers or motoneurons, $100 ð r$ should we explore unexplored rheumatological avenues?

1008ince it is treated with exercise: does it come down to simply being physically 100ఖnfit, or are mitochondria and oxidative stress a smaller piece of a bigger 101థicture? Does lack of exercise lead to sicca and Raynaud's phenomenon? 101Mitochondrial myopathies have moth eaten appearance but apparently not 1016ERD and tenderness in certain points. Perhaps it is due to obesity, though, 101飞ushing's syndrome often leads to high cortisol levels, depression, adiposity, 1014nd metabolic conditions, but apparently not wheezing and CWP.

$1015 f$ it is part of menopause, what is "juvenile fibromyalgia"?

1016here are those who suggest fibromyalgia is not a real entity or that it is 1017aused by sleep disturbances. However, the relatively modest efficacy of 1018ntipsychotics and/or melatonin and/or z-drugs implies it is probably neither 1019n imaginary hallucination nor due to lack of sleep. 
10201eworthy, two parallel mechanisms (or more) might be at work and are 102 not necessarily incompatible with each other. Gupta et al. studied CWP in 1028omatising individuals. They conclude that while a high tender point count is 102 3ssociated with the onset of new CWP, a low pain threshold at baseline is 1024ot. ${ }^{182}$ With our new view of MPS it is logical, since tender point count would 102\$e a marker for a fascial tensional pathology, leading to widespread pain and 1026 lower pain threshold later.

Doesdrzascial armoring" fill in gaps regarding some of these anomalies? If affecting the $1028 \mathrm{k}$, a constrictive tissue in the chest might be able to impair lung function and controbate to wheezing and chest tightness. If involving a compression by the cervioabfascia, it might affect salivary ducts/glands, affecting salivation and sicca. A link 103ahenomena like seizures/pseudoseizures will be suggested below when men10abing the myodural bridge. Interestingly, studies suggest tricyclic antidepressants can downregulate myofibroblasts and ACTA2 gene expression, ${ }^{183,184}$ and 1 scorthe SSRIs may actually enhance them; ${ }^{185}$ It seems gp120 has a stimulatory effeco3m myofibroblasts as well. ${ }^{71,186}$ We could similarly predict that the pathogen BornelB pathobogy. Thus, resulting in an infectious version of fibromyalgia with or without pronOBisced inflammation. Borrelia and fibroblast co-cultures show a significant indulctsen of type I collagen mRNA after 2 days $(p<0.02)$ and a significant upregutation of mRNA expression of TGF- $\beta(p<0.01) .{ }^{187}$ Since TGF- $\beta$ is a cardinal signad4or myofibroblast $\alpha$-SMA synthesis, this may explain why, of all infections, LymbodRsease (and not viral encephalitis or infective transverse myelitis) is strongly assoldabed with fibromyalgia. Biopsy studies of fibromyalgia patients find that, in 
peripheral fibroblasts, TGF- $\beta$ gene expression is significantly higher in fibromyalgia pati 1045 compared to controls. ${ }^{130}$ If one accepts only alternative theories: why and how1046GF- $\beta$ expression two to three-fold higher in peripheral fibroblasts of fibra04y/algia patients $(p<0.001)$ ? Due to the marked similarity to fibromyalgia, such eventost8an be expected in connective tissue in "post COVID-19 syndrome". Unưdatisthi et al. suggest the infiltration of neutrophils, macrophages and CD4+ T lympareytes in COVID-19 patients can promote the activation of fibroblasts to myoffotsnoblasts in heart. ${ }^{188}$ SARS-CoV-2 may induce the trans-differentiation of adiprosptes or pulmonary lipofibroblasts into myofibroblasts, cells that play an inte fibraosyalgia-like symptoms would arguably be a sequela of infection rather than an

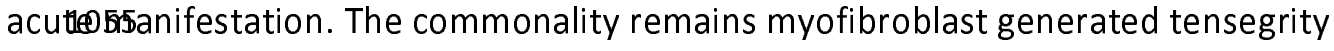
tensi०̄6

A fevoff the research methods investigating fibromyalgia assume there is no periptefral organic lesion that causes the pain experienced. Magnetic resonance studies9of the brain do not necessarily distinguish between a purely neuroplastic CWR orod one arising from the periphery. Therefore, it would benefit our undestanding of central mechanisms if studies had a tool to identify whether mechowrical fascial pain due to myofibroblasts is present in the individuals being studied, and if the pain measured arises from the periphery or not.

One10164ly suggested that in fibromyalgia, a global pathology involving tryptophan migto6rome at the expense of other serotonergic operations such as in the brain. ${ }^{190}$ A manosensitive effect can trigger serotonin release from enterochromafin or 
neuf0ø̄̄docrine cells. ${ }^{191,192}$ Serotonin is involved in the cellular signaling of conøe68ive tissue cells. ${ }^{193,194}$ Studies of fibromyalgia patients indicate an elevated level@fsserotonin in myofascial tissue and platelets, while a decreased level of tryptophan and its derivatives, serotonin and kynurenine, is observed in the blood and107 brain. ${ }^{195-201}$ Some fibromyalgia patients are found to have decreased rate of tranisport of tryptophan across the blood brain barrier. ${ }^{190}$ Theoretically, a peripheral dephetran of biogenic amine metabolites may play a role in the association between mod®zAsorders and fibromyalgia in some individuals, and might explain why antideressants seem to have such a limited efficacy in a subset of them.

\section{Complete resolution of fibromyalgia}

Seveal7studies point to a peculiar phenomenon. Saber et al. ${ }^{202}$ witness high rates of complese resolution of fibromyalgia following laparoscopic Roux-en-Y surgery. By whiđb79echanism does a longstanding persistent central sensitization completely resollo8following abdominal surgery? Could this be a result of an overlooked fasclozamy? The authors of that study suggest resolution may be due to weight loss, incræased physical activity, and lifestyle changes. However, this idea does not align witherisodings of Adkisson et al. ${ }^{203}$. They studied the effect of parathyroidectomy on fibra08algia among 76 patients diagnosed by specialist or primary care physician. Findiags show that 21 percent of fibromyalgia patients discontinue all fibromyalgia drugąedications after parathyroidectomy, and 89 percent have relief of one or morko bromyalgia symptoms postoperatively. These changes occurring as early as one108\&k after neck surgery. ${ }^{203}$ Yet, $11 \%$ of patients had no improvement in sympesons at all. The authors explain the complete resolution in 21 percent by 
suggegtong a misdiagnosis, ie, these patients actually did not have fibromyalgia in the firstiplare. However, if this was true, we might expect these individuals to cluster morkotewards the group not diagnosed by a specialist. Surprisingly, 23 out of 76 weræasianosed by a rheumatologist, out of them $96 \%$ had symptom improvement, and 170\%\% were able to discontinue all medications after parathyroidectomy.

Unc symporns were diagnosed by a primary care physician $(p<0 \cdot 05) .{ }^{203}$ The statistics sugge97some non-random phenomenon caused a bimodal-like distribution. In light of this dydy, it might be hypothesized fibromyalgia is related to a parathyroid cause. Howeger, a similar enigma is found with irritable bowel syndrome (IBS), a functional disor with no definite organic findings and closely associated (or overlaps) with fibramodalgia. Some suggest fibromyalgia and IBS are actually the same entity. ${ }^{154}$ IBS is shawn to be relieved below Rome II criteria in 80 percent of patients after laparbasopic fundoplication for GERD. ${ }^{204}$ Looking for a common denominator one can hupbothesize that relief is achieved due to intense pain exposure and general anestlossia that resets the brain circuits, somewhat similar to electroconvulsive theraposcombining gate control. But it does not align with findings that tonsillectomy increde区s risk of IBS, ${ }^{205}$ that umbilical hernia repair surgery seems to predispose to IBS, 10908 nd that patients with fibromyalgia have a higher incidence of suffering IBS aftertappendectomies. ${ }^{207}$ Moreover, hysterectomy, with or without oophorectomy, seemsito worsen fibromyalgia. ${ }^{208}$

OddI $¥, 1$ why does the location and type of surgery seem to regulate the positive or negative impact on these somatic conditions? Indeed, it was suggested in this 
literatuBe review that MPS/TrPs can cause chronic changes in bowel habits. Should we susfect that in these associated disorders, the connecting motif is connective tissue15This may imply that the location of the surgery has different effects on fascia, evenremotely, due to- and regulated by- tensegrity forces. The lateral raphe and common tendon of the transversus abdominis are suggested to form connections betwees, and transfer tensions between, the abdomen and the paraspinal muscles and isheath. ${ }^{14,209}$ This can explain how laparoscopy might release a compression on the $\mathbb{D} \mathbb{R} \boldsymbol{\theta}$. Interestingly, this would mean the clustering of patients experiencing ben®fizpost-parathyroidectomy towards the group diagnosed by a rheumatologist, and throse not experiencing benefit towards the group diagnosed by primary care physicazn, isn't due to misdiagnosis but precisely because rheumatologist really identtefthose with fibromyalgia statistically significantly more accurately. According to C hysteremy impair it? What about below knee amputation?

\section{Compeassion vs. global percutaneous needle fasciotomy}

Studiessshow obesity induced connective tissue fibrosis is dependent on mecharosensitive signaling. ${ }^{210}$ Fibrosis, via myofibroblasts, alters subcutaneous tissuezolasticity and increases connective tissue rigidity and stiffness. ${ }^{210}$ Thus, obesity might tre associated with fibromyalgia by way of mechanically compressing fascia withlikgher forces. A study in vivo suggests applying tension on skin induces myofflisoblasts. ${ }^{74}$ Therefore, by this same rationale we might expect a sedentary indirichatal that tends to wear tight clothes and accessories that mechanically comprass fascia to be at higher risk for this pathology over time. It was shown the 
assoläaion between a higher incidence of fibromyalgia and estrogen is unlikely. ${ }^{202,211}$

Estrogen is suggested to inhibit myofibroblast differentiation and is associated with lowenf8scial stiffness, ${ }^{212-215}$ and hormonal contraceptives may reduce the risk of fibrambealgia in women. ${ }^{216}$ Some suggest fibromyalgia may be linked to mendpause. ${ }^{217}$ This could be part of the explanation of why fibromyalgia is more prevalıht in certain females. Other studies show that applying a splint or mechanical tensi ФA2induces myofibroblasts, ${ }^{80}$ and ponytails/hijabs/braziers appear to cause myơfaßzial pain. ${ }^{218-222}$ This phenomenology appears to be similar to, or the same as, the $\$ 1$ d4practice of applying bandages to treat "rheumatism" patients (William Balfळ1 451815$),{ }^{223}$ meaning: modulation of the tensegrity structure and/or induction of strkes6 shielding but failing to resolve overall tension (eg, the case of Mrs. M. p1791801147erestingly, experimental models of restraint stress apply mechanical restraity and/or limit movements..$^{224-228}$ These models seem to induce mechanical andidald allodynia, depression and anxiety like behavior, gut dysmotility, and other phemb50ena. ${ }^{224-228}$ Thus, one might wonder what is the pluripotent entity that restifäntt stress tries to model? Is it only psychological stress?

In ađ\$502ase, perhaps a treatment or prophylaxis that applies multiple needles in differksst areas of the tensegrity system, could be utilized as a global percutaneous needlestasciotomy. The theoretical end purpose for this treatment would be to passivisby lower global fascial stiffness beneath the threshold necessary for myofils6oblasts activity ( 10-20 kPa) and slowly experience a tensional collapse. Elast@E్gaphy studies of fibromyalgia and MPS are scarce. Some studies found fascia of pitsents with myofascial pain measures statistically significantly higher on shear 
wavel begstography, and they have increased peri-muscular connective tissue thickm@s and ultrasound echogenicity. ${ }^{229,230}$ It was found that needling treatment reduces pain..$^{231-235}$ Studies suggest needling significantly lowers the shear modulus of myderascial tissue as measured by elastography $(p<0.01),{ }^{95}$ causes mechanical change3 at the point of insertion and at a distance, ${ }^{91,102,}$ causes windup of the con๓๓6屯ive tissue, ${ }^{105}$ and improves perfusion to the area. ${ }^{236}$ Meta-analyses and syst\$n65tic reviews find that needling improves pain and stiffness in people with fibrambalgia and MPS. ${ }^{233,234,237}$ Support for this modality's capability of improving perflusfön is found in a study showing infiltration of TrPs reduces symptoms of interrarestent claudication. ${ }^{238}$ Symptomatically, a person constantly exerting effort agaimbsesuch forces of a suffocating fascia would likely feel chronic fatigue and soreliass, while accumulating nociceptive substances in muscles in a chronically tonic

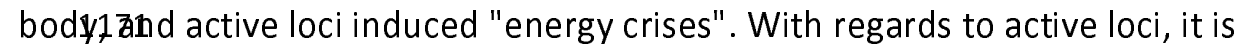
possibte the cell has its own ways to oppose this abnormality. When synaptic

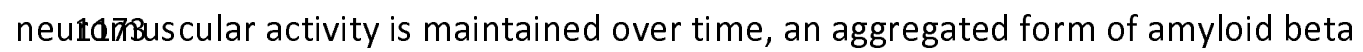
is selellino interfere with Ach release ex vivo. ${ }^{239}$ One adopting this biological ethos shouldt ถึot be surprised if amyloid beta has some role in "fascial armoring", because

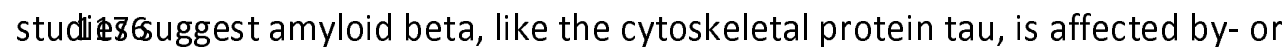
compañsates for- mechanical stress. ${ }^{240-244}$

At ledst8we might want to exclude an organic fascial cause before perceiving these Cas®sı $\gtrsim 9$ purely psycho-functional disorders, even if the full mechanism is still unclebro Is there enough empirical evidence to recognize MPS and fibromyalgia as honørable organic diseases, like any other? Medicine is used to entities that are 
eithథr8bnmune related, infectious, malignant, endocrine, metabolic, genetic, cardii\$83scular, neurologic, traumatic, or toxic, but not familiar with many mechidical ones. If medicine overlooked another system causing pain besides fascia, like 1nßsgumentary or skeletal, it would probably lead to overlying on psychology to expla186hat pain. Maybe it is not some mechanism that has yet to be fully discolered or measured. Maybe it has been both discovered and measured yet oved $\$ 8$ ked and misinterpreted. It is difficult to explain all the empirical evidence relatinggto fibromyalgia (eg, association with hypermobility syndrome and the comple resolution soon after surgery) while relying on central sensitization and stre\$1 somatization alone. Therefore, investigating a link between fibromyalgia and 1 alperipheral mechanical process might benefit our understanding.

The 1eligthusiast of the principle of Occam's razor (ie, minimize multiplication of entitinesf might consider seeing other functional entities that are known to be assoldiased with pluripotent TrPs, ${ }^{2,4,12,43,245,246}$ as "MPS"/"fibromyalgia" that is locali to certain anatomical areas; coupled with the reciprocal central nervous systథrazhanges. "Kelley's textbook of rheumatology" and others suggest functional somalts syndromes to be on a continuum of one entity with fibromyalgia. ${ }^{122,154,167}$ Mydfeseial TrPs reproduce the pain pattern of fibromyalgia and are related to widespøead mechanical hypersensitivity. ${ }^{247}$ A study found that the topography of fibrabodalgia tender points consists mostly of myofascial active TrPs ( $r=0 \cdot 78$, p<0:1001). ${ }^{248}$ In addition, MPS and fibromyalgia are suggested to be two sides of the same20ain. ${ }^{2,249}$ Etymology does not necessarily reflect pathophysiology, but the term "fib1807yalgia syndrome" basically carries the same meaning as "myofascial pain 
synd205e" but in Greek. The analysis based on this scoping review offers one medratical aspect as a part of a common rheumapsychoneurological mechanism.

\section{Final zoste and future potential}

Basedorn this review, it seems that fascia is an intelligent and sophisticated tissue network, at least like any other tissue network we know. It is shown myo/fibroblasts havezlatp junctions that can couple and directly communicate with each other (Xu et al. 2021D) ${ }^{250}$ and with other types of cells (with heart, ${ }^{251}$ hair follicles, ${ }^{252}$ cancer cells,2533etc.)..$^{51,254-258}$ These can contract as a unit or in patterns, ${ }^{259,260}$ affecting the orgal2' $\$$ Afunctionality. ${ }^{53,261-268}$ If this theoretical model of myofibroblast-generatedtenslegrity-tension is verified empirically, it might be worth further exploring the possibs16ty that they can couple in vivo (directly, or indirectly through myocytes/glial cells)2tbo nerves. Studies suggest the meninges might be coupled to the cerebral cortex180 form one large network with myo/fibroblsts. ${ }^{269-272}$ The myodural bridge conns the extracranial occipital fascia with the dura. ${ }^{273}$ Myo/fibroblasts seem to forma2body-wide cellular network; They can respond to mechanical cues and exhibit sponæaneous calcium oscillations and synchronized contractions, ${ }^{62,258-260,267,274-276}$ and fibrabbast themselves can induce contracture through actin beta and gamma patharas/s. ${ }^{277}$ We could consider the hypothetical possibility that this dynamic bodywidezenanoelectrical network of cells and fibers has an overlooked interplay with the metwork of the human nervous system. This idea might disguise some of the pathepábysiology of self-psychosomatics and potentially help us understand why a 
remazkæble 17 percent of primary care patients are diagnosed with somatic symptem disorder (SSD) (defined in studies as at least four or more unexplained symptzons) ${ }^{278}$, why tender point counts are predictors of CWP in somatising subjez:30, ${ }^{182}$ and why SSD is associated or overlaps with fibromyalgia. There are those wholieve tensions in the body are closely linked to our emotions and personality (eg,AABReich and A. Lowen). ${ }^{279,280}$ We know biology does not separate itself into differesst medical specialties like we do occupationally.

Last1p,3if myofibroblast can engulf their surroundings, ${ }^{281}$ and in certain conditions are ablelæapresent antigens via MHC class II to T cells, ${ }^{282-285}$ then we might want to examibe the potential role of myo/fibroblast fascial networks (or differestiated/somatic-mutated clone populations) in immune related conditions. Empipis suggest a link between fibromyalgia and other rheumatological disorders, and 19239arently, a study from 1990 of 20 patients with fibromyalgia suggests the maj\$RitQ have anti smooth muscle antibodies. ${ }^{286,287}$

On 12 spectrum of "normality" we may all have "MPS" to some extent, technically speaking. It seems to be a question of how much we have and how much it affects our 1 bfe3 A tradeoff is still being made, no longer by biology but by humans. Not regarathg the molecular design of fascia, but it is an ongoing tradeoff between not movib5and moving. As it seems to be a natural condition worsened by an un-natural lifestag we may say living sedentarily misses our evolutionary target (ie, a "biolegical sin"). It is interesting a study by Younger et al. finds patients with myoffasial pain have changes in grey matter in the hippocampus, anterior insula, and1eifgulate cortex, among several areas: ${ }^{288}$ Forgetting our evolutionary purpose 
seem2500 impair our memory, while cognitive detachment from our body-awareness seenrostlo impair our cognition, and because the biogenic amine metabolites are low, the Looking through the given titles of these entities, we might find what we most want to fine $\$ 4$ where we least want to look. A body that cannot move with total freedom will 105/5 a mind that is seldom totally free of dis-ease. This aligns with the notion thatte body and the mind are accepted to be one being. Just as we can say music is a "collerction of noises" or a "divine melody", so may we say MPS is "pulled muscles" or a1'255scinating disorder of the fascia". Assembling these conclusions and concepts to cliesively connect this medical puzzle is the easier part of this not so easy effort. The1 challenge now being the research needed to verify or disprove them, and movidg]forward with evidence on this topic while moving ourselves...

1262

\section{Fiquire62: Illustration of needling in fascial tensegrity framework}

To gras this framework the reader may try and imagine a geodesic dome connected not by straigh 25 Solid bars, but imagine it connected by extremely thin sheets of spandex/elastane. Eack 3 ean change its spring constant. Then imagine continuously applying external forc 4860 this dome from different directions.

1268

Inseithe of needles in many "scattered" points while at rest will allow the system to realign apprbpithtely and accordingly to the inherent internal forces or pullies, ${ }^{22}$ eg, the skeleton. Now the rezadter may imagine this dome only in the shape of a human, and it can move.

1272 


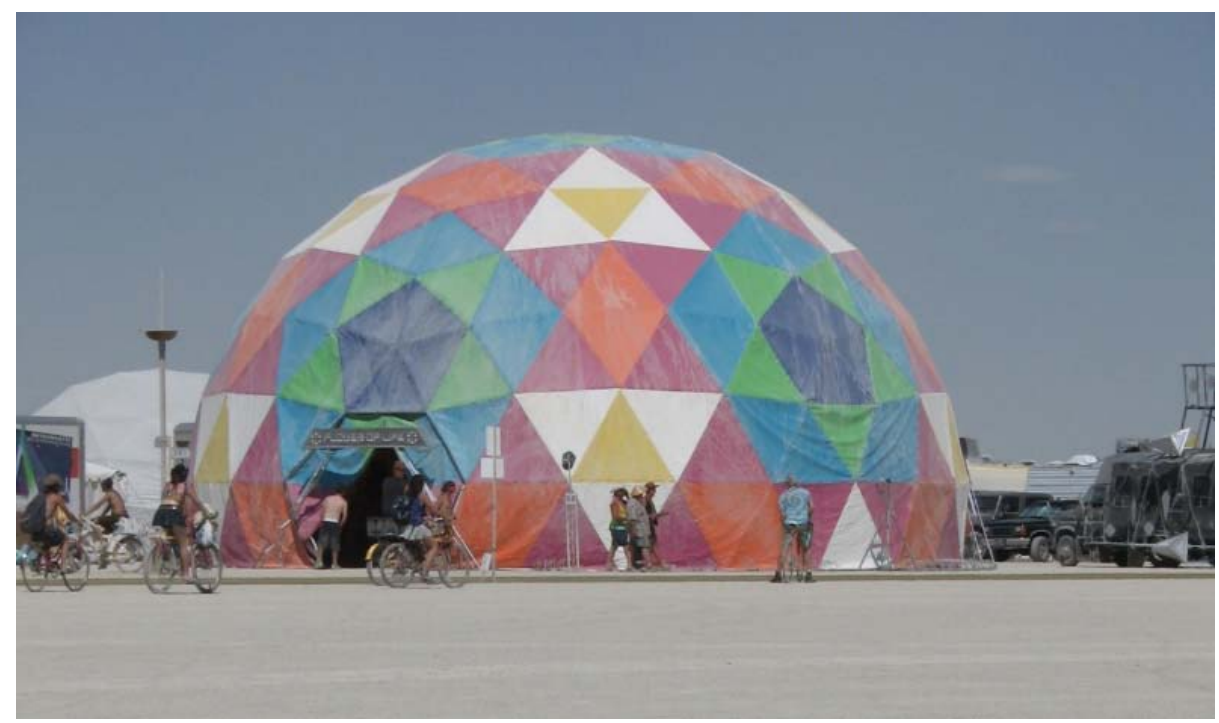

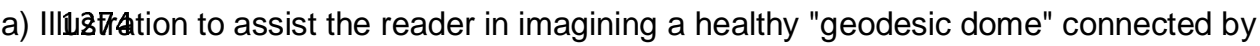
spardex sheets (fascia)

With1pęfrmission from PACIFIC DOMES Inc. www.eventdome.wordpress.com/ 1277

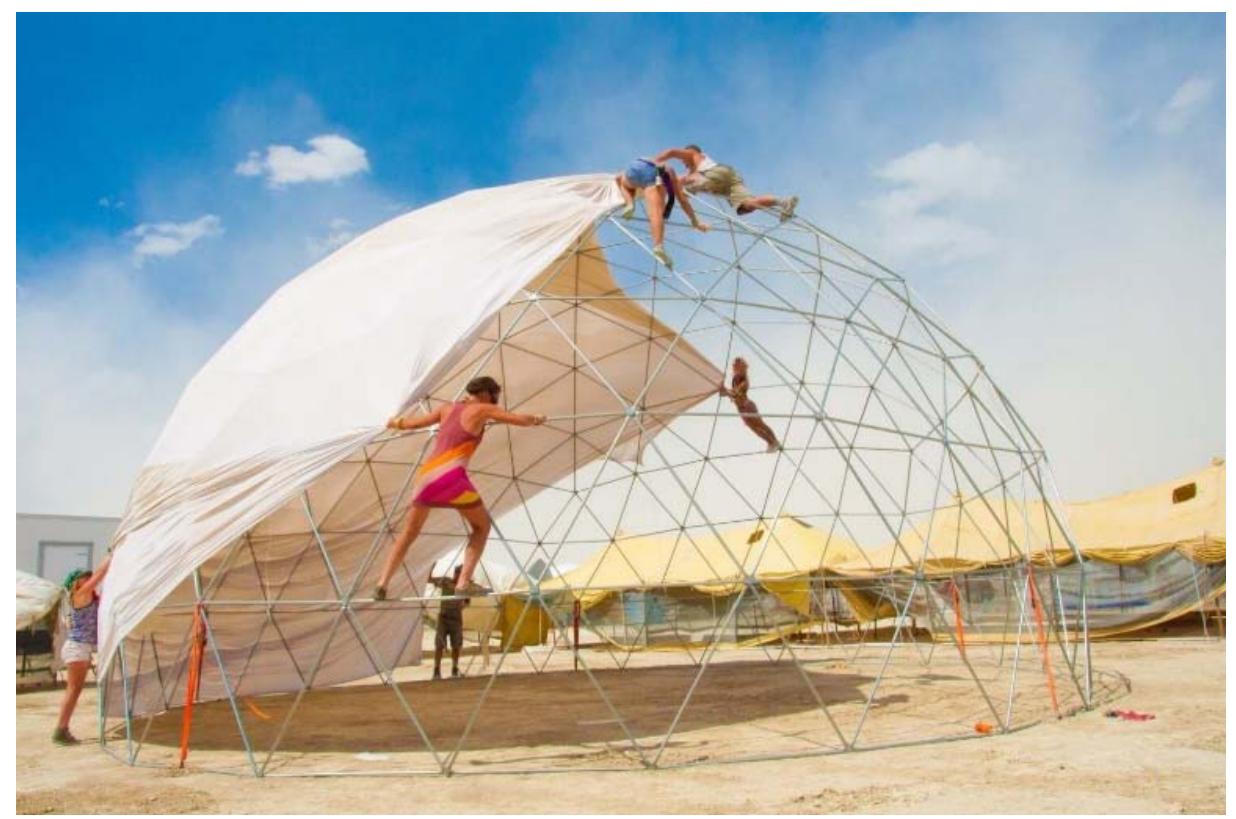

b) N\$2 netwior8cof nodes.

With1p8dmission from Dome guys international www.domeguys.com 


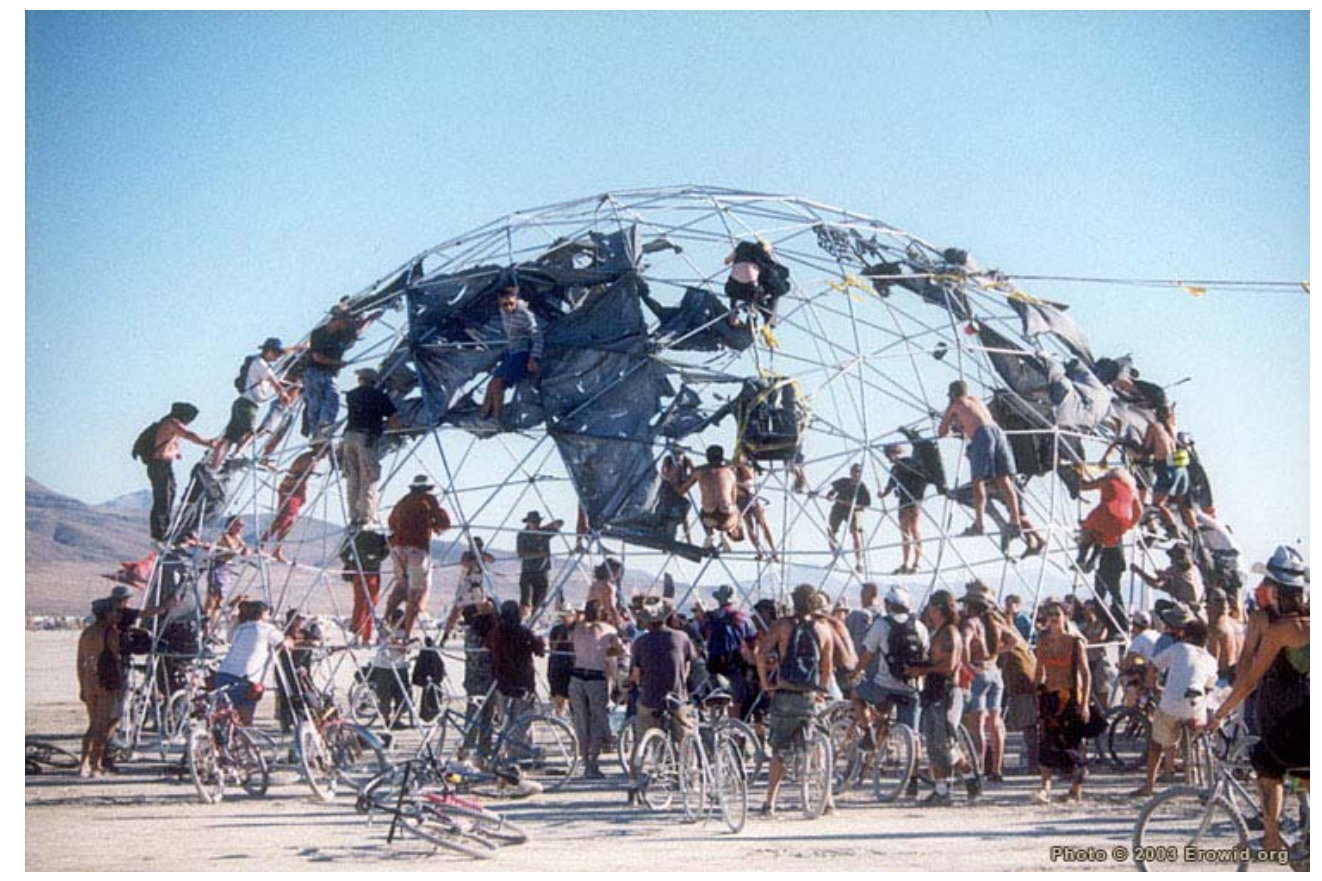

c) Ch284ic over-strain causes pathological changes in fascia or changes of myofibroblast and

smoळ18 5 nuscle fibers inside the fascia. The fascia fails to distribute forces properly and keep the integrity of the structure. Structures on the dome and inside the dome are affected.

With128\%mission from PACIFIC DOMES Inc www.pacificdomes.com

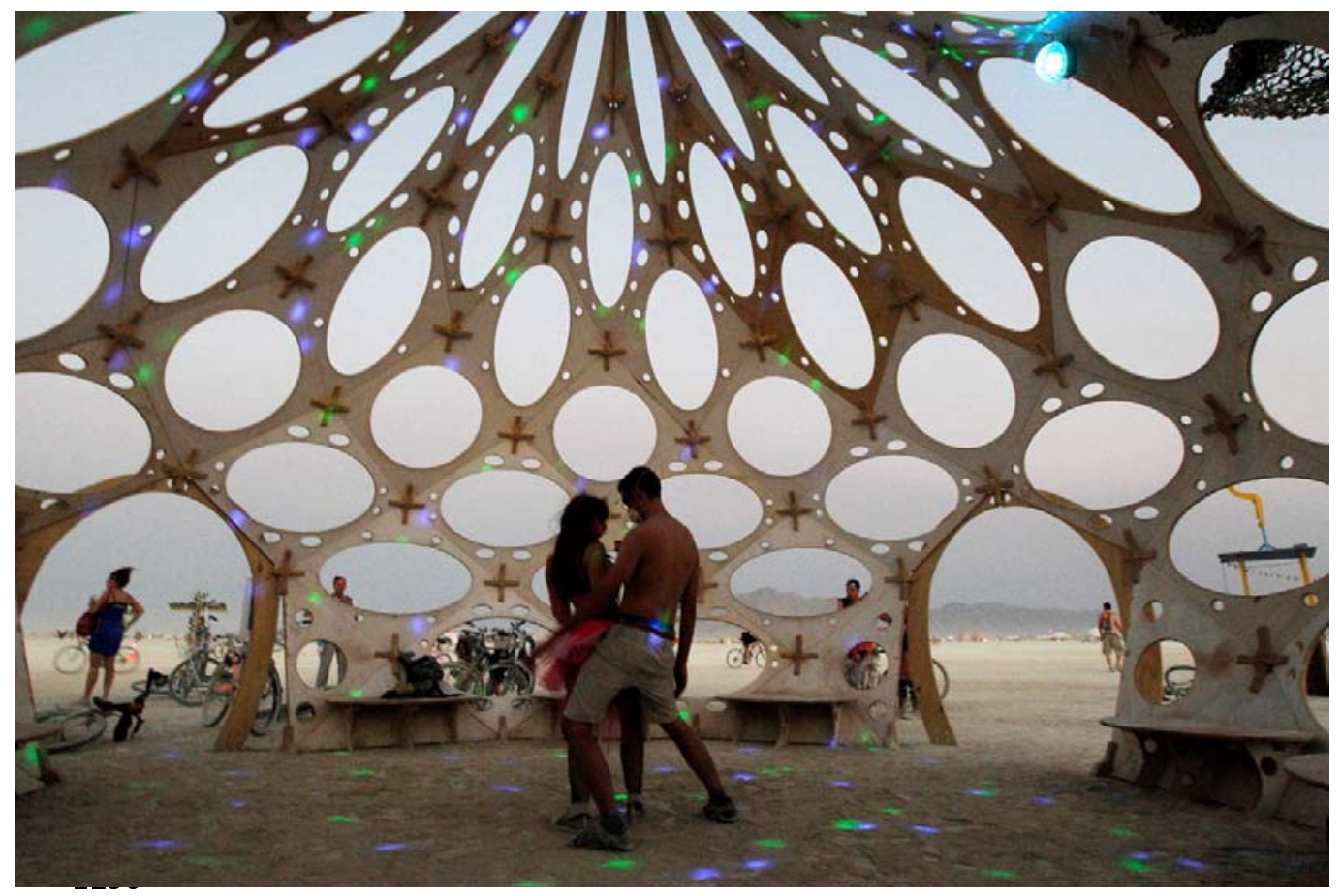


d) Aftę're-setting' the system with needling or other techniques: "regeneration and growth of new12002nections over time should be determined by natural forces and pullies". ${ }^{22}$ New areas in thezascia serve as points of focus for changes and realignment. Structures can relax and return2804the minimum energy state. Fascia is always subjected to remodeling pressures and respires to the local mechanical state. However, if spatial deposition of fibers is altered with resp 2960 physiological conditions, the rebuilding will be pathological. ${ }^{22}$ Mobilization encoldeg correct healing in order to avoid formation of fibrosis. ${ }^{22}$

TakAR Jim Bourg, with permission from REUTERS News Agency.

1299

1300

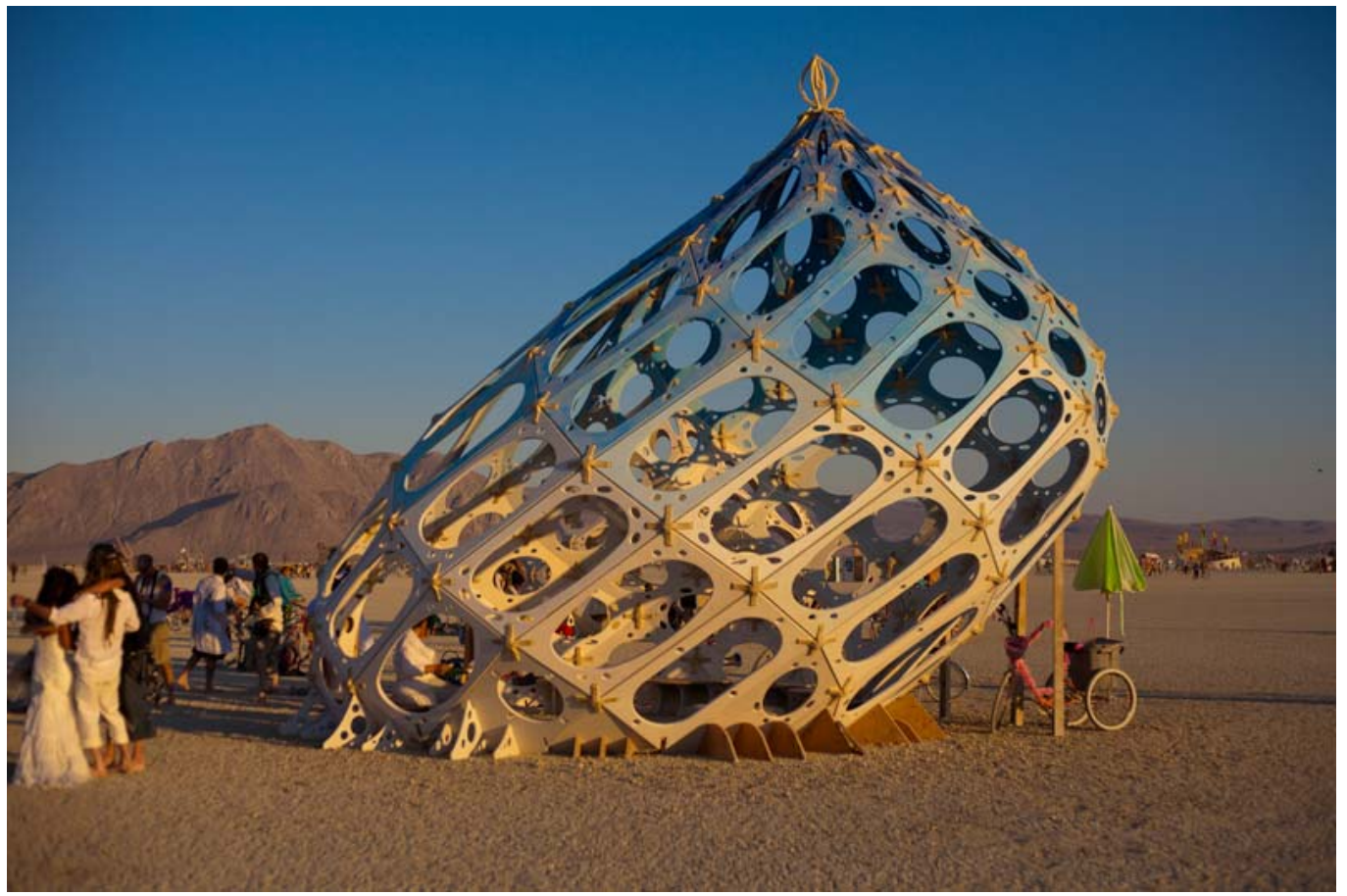

e) A13ological entity in the form of a tensegrity abnormality, it is both systemic and asynineetrical or seemingly "unilateral".

Photb304h permission from, and taken by, Aaron Neilson-Belman 


\section{Limitäions:}

The limitation of this scoping review is that a sole researcher evaluated the studieoglt is based on other empirical studies where some are in vitro studies, as ment300ed in parts of the discussion. Being a scoping review, although a broad searcłing strategy was applied, not every topic was searched systematically. A

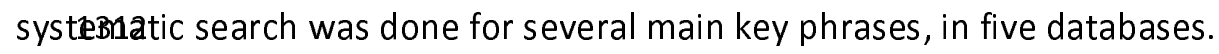
Systeßmatically searching for relevant side topics (ie, topics not defined in the key phrasess) was not feasible, unfortunately. For side topics, an attempt to find a reliable sounce bf information, like a textbook or study (or both), was the strategy to gather infollanation. In such cases an attempt to cite more than one study was made. Worth noting ho on topic studies were found when searching "fibromyalgia myofibroblast" or "fibromyalgia alpha smooth muscle actin". The cytokine profile and the topic of vitađ3in

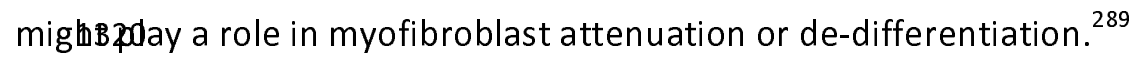

Contabations: this work was done by the sole researcher and author of this man138cript including conception, organization, literature review, integration of inforląastion, findings analysis, manuscript preparation and writing.

Ackmbededgements: Professor Pnina Ohanna Plaut for assisting with methodology and 1edizing. Dr. Bronya Gorney for assisting with editing. Carrie Rodomar, librarian of UniuBR3ty of Nicosia Medical school, for assisting with methodology. 
medRxiv preprint doi: https://doi.org/10.1101/2021.07.06.21260111; this version posted August 29, 2021. The copyright holder for this preprint (which was not certified by peer review) is the author/funder, who has granted medRxiv a license to display the preprint in perpetuity.

All rights reserved. No reuse allowed without permission.

Confke日of interest: The author declares no conflict of interests.

FundB3g: none

1331

1332 


\section{Referabies:}

1. 1335 NHO Scientific Group on the Burden of Musculoskeletal Conditions at the Start of the N36 Millennium. ( 2003 : Geneva, Switzerland). (2003). The burden of musculoskeletal condiBians at the start of the new millenium : report of a WHO scientific group. Geneve : WorldB Bealth Organization. https://apps.who.int/iris/handle/10665/42721. Accessed NovêBäer 2020

2. 1340vww.uptodate.com search "myofascial pain syndrome", "pelvic pain", "tmj" accełsßd November 2020. "Trigger points" "Fibromyalgia", "differential diagnosis of fibrổ3algia" accessed April 2021, "Chronic exertional compartment syndrome" August 2021343

3. 134Kasper DL, Fauci, A. S., Hauser, S. L., Longo, D. L. 1., Jameson, J. L., \& Loscalzo, J. Harnstat5s Principles of Internal Medicine, 20e. New York; 2018. Pages 222-223, 2637-2639, $2644-3696$

4. 134Giamberardino MA, Affaitati G, Fabrizio A, Costantini R. Myofascial pain syndromes and 1BAB evaluation. Best Pract Res Clin Rheumatol. 2011; 25(2):185-98.

5. 1349iegfried Mense DGS, I. Jon Russell. Muscle Pain: Understanding Its Nature, Diaghz585, and Treatment. Philadelphia; 2001 Pages 1-10.

6. 1351ucas N, Macaskill P, Irwig L, Moran R, Bogduk N. Reliability of physical examination for dizg̨arosis of myofascial trigger points: a systematic review of the literature. Clin J Pain 2009;3\$3(1): 80-9.

7. 1354 uintner JL, Bove GM, Cohen ML. A critical evaluation of the trigger point phenabłenon. Rheumatology (Oxford) 2015; 54(3): 392-9.

8. 135 Meister MR, Sutcliffe $S$, Ghetti C, et al. Development of a standardized, reproducible

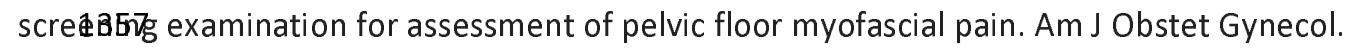
2019;358(3):255.e1-255.e9. 
medRxiv preprint doi: https://doi.org/10.1101/2021.07.06.21260111; this version posted August 29, 2021. The copyright holder for this preprint (which was not certified by peer review) is the author/funder, who has granted medRxiv a license to display the preprint in perpetuity.

All rights reserved. No reuse allowed without permission.

9. 1359imons DG, Janet G. Travell, and Lois S Simons. Travell \& Simons' Myofascial Pain and DBgounction: The Trigger Point Manual. 2nd ed. Baltimore; 1999. (Pages xi- 87, 940-955)

10. 1361 Wheeler AH. Myofascial pain disorders: theory to therapy. Drugs 2004; 64(1): 45-62.

11. $136 \mathbb{F}$ leckenstein J, Zaps D, Rüger L, et al. Discrepancy between prevalence and perckBred effectiveness of treatment methods in myofascial pain syndrome: results of a cros\$3 tional, nationwide survey. BMC Musculoskelet Disord 2010; 11: 32.

12. 136Do TP, Heldarskard GF, Kolding LT, Hvedstrup J, Schytz HW. Myofascial trigger points in m1giøne and tension-type headache. J Headache Pain. 2018;19(1):84.

13. 136Klotz SGR, Ketels G, Löwe B, Brünahl CA. Myofascial Findings and Psychopathological

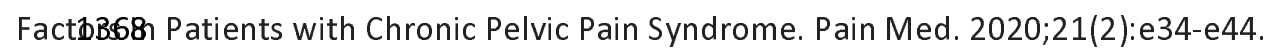

14. 1369Villard FH, Vleeming A, Schuenke MD, Danneels L, Schleip R. The thoracolumbar fascib3 30 atomy, function and clinical considerations. J Anat 2012; 221(6): 507-36.

15. 137 Atlas of Human Fascial Topography. Fascia Atlas Leipziger Universiätsverlag; 2018.

16. 1372 angevin HM, Keely P, Mao J, et al. Connecting (T)issues: How Research in Fascia Biold87Ban Impact Integrative Oncology. Cancer Res. 2016;76(21):6159-6162.

17. 1374arker PJ, Briggs CA. Attachments of the posterior layer of lumbar fascia. Spine (Phila Pa 19365. 1999; 24(17):1757-64.

18. 137 Nordez A, Gross R, Andrade R, et al. Non-Muscular Structures Can Limit the Maximal JointlBヌ̄̄ge of Motion during Stretching. Sports Med. 2017; 47(10):1925-1929.

19. 1378 kbar M, McLean M, Garcia-Melchor E, et al. Fibroblast activation and inflammation in fr $\mathbf{\nexists z} \mathrm{z} \Theta$ shoulder. PLoS One. 2019;14(4):e0215301.

20. 138 đeng YJ, Sun XP, Yang J, Wu WH, Xu XH, Yan YP. Mechanical properties of nasal fascia and pasibsteum. Clin Biomech (Bristol, Avon). 2003; 18(8):760-4.

21. 1387ahia LH, Pigeon P, DesRosiers EA. Viscoelastic properties of the human lumbodorsal fascib38Biomed Eng. 1993; 15(5):425-9. 
medRxiv preprint doi: https://doi.org/10.1101/2021.07.06.21260111; this version posted August 29, 2021. The copyright holder for this preprint (which was not certified by peer review) is the author/funder, who has granted medRxiv a license to display the preprint in perpetuity.

All rights reserved. No reuse allowed without permission.

22. 1384avan PG, Stecco A, Stern R, Stecco C. Painful connections: densification versus fibrolk385f fascia. Curr Pain Headache Rep 2014; 18(8): 441.

23. 138@ielson-Wong E, Glinka M, Noguchi M, Langevin H, Badger GJ, Callaghan JP. Acute Surgled7njury Alters the Tensile Properties of Thoracolumbar Fascia in a Porcine Model. J Bion18818 Eng. 2018; 140(10):1010121-7.

24. 138氐agawa E, Nimura A, Nasu H, Kato R, Akita K. Fibrous Connection Between Cervical Nerue390d Zygapophysial Joint and Implication of the Cervical Spondylotic Radiculopathy: An Anatbailic Cadaveric Study. Spine (Phila Pa 1976). 2021;46(13):E704-E709.

25. $1398 \mathrm{Nertsch} \mathrm{JJ}$, Melvin J. Median nerve anatomy and entrapment syndromes: a review. Arch1B日ßss Med Rehabil. 1982;63(12):623-7.

26. 139 Konno S, Kikuchi S, Nagaosa Y. The relationship between intramuscular pressure of the 13ebspinal muscles and low back pain. Spine (Phila Pa 1976). 1994; 19(19): 2186-9.

27. 1394McCombe D, Brown T, Slavin J, Morrison WA. The histochemical structure of the deepBSCia and its structural response to surgery. J Hand Surg Br 2001; 26(2): 89-97.

28. 1398Marinelli L, Cacciatore I, Eusepi P, et al. Viscoelastic behaviour of hyaluronic acid form 139 ions containing carvacrol prodrugs with antibacterial properties. Int J Pharm. 2020;580:119306.

29. 140Matteini P, Dei L, Carretti E, Volpi N, Goti A, Pini R. Structural behavior of highly condeftezated hyaluronan. Biomacromolecules 2009; 10(6): 1516-22.

30. 140ßoung, Barbara (Pathologist). Wheater's Functional Histology : a Text and Colour

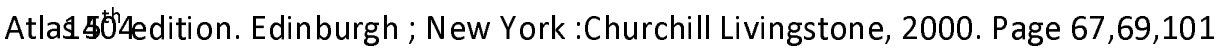

31. $1405 /$ leeming A, Pool-Goudzwaard AL, Stoeckart R, van Wingerden JP, Snijders CJ. The posteflar layer of the thoracolumbar fascia. Its function in load transfer from spine to legs. Spine4((Phila Pa 1976). 1995; 20(7):753-8. 
32. 1408un D, Zoe M, Johnston V, O'Leary S. Physical risk factors for developing non-specific neck1 $19 \theta$ in office workers: a systematic review and meta-analysis. Int Arch Occup Environ Health DDo17; 90(5): 373-410.

33. 141 basabe R, Sakamoto J, Goto K, et al. Effects of joint immobilization on changes in myofihrzblasts and collagen in the rat knee contracture model. J Orthop Res.

2011;\$5\$9):1998-2006.

34. 1414Williams PE, Goldspink G. Connective tissue changes in immobilised muscle. J Anat 1984;4138 (Pt 2): 343-50.

35. 1416ima LV, Abner TSS, Sluka KA. Does exercise increase or decrease pain? Central mechantsms underlying these two phenomena. J Physiol. 2017; 595(13):4141-4150.

36. 141\&aldeira P, Fonseca ST, Paulo A, Infante J, Araújo D. Linking Tensegrity to Sports Tean40 \&lective Behaviors: Towards the Group-Tensegrity Hypothesis. Sports Med Open 2020;48(a): 24 .

37. 142Tadeo I, Berbegall AP, Escudero LM, Alvaro T, Noguera R. Biotensegrity of the extradedular matrix: physiology, dynamic mechanical balance, and implications in oncology and 142chanotherapy. Front Oncol 2014; 4: 39.

38. 1424Wilke J, Schleip R, Yucesoy CA, Banzer W. Not merely a protective packing organ? A revid26f fascia and its force transmission capacity. J Appl Physiol (1985). 2018;124(1):234244.1426

39. 142 Harty J, Soffe K, O'Toole G, Stephens MM. The role of hamstring tightness in plantar fascilttz\& oot Ankle Int. 2005;26(12):1089-92.

40. 1429Nilke J, Krause F, Vogt L, Banzer W. What Is Evidence-Based About Myofascial Chain\$30 Systematic Review. Arch Phys Med Rehabil. 2016;97(3):454-61.

41. 1437hou JP, Yu JF, Feng YN, et al. Modulation in the elastic properties of gastrocnemius musthe3Reads in individuals with plantar fasciitis and its relationship with pain. Sci Rep 2020; 10(1):43870. 
42. 1434iu L, Huang QM, Liu QG, et al. Effectiveness of dry needling for myofascial trigger poinf 35 sociated with neck and shoulder pain: a systematic review and meta-analysis. Arch Phys1ABed Rehabil. 2015;96(5):944-55.

43. 143 Moldwin RM, Fariello JY. Myofascial trigger points of the pelvic floor: associations with14Bogical pain syndromes and treatment strategies including injection therapy. Curr Urol1Aeig 2013; 14(5): 409-17.

44. 144氏onno T, Aota Y, Kuniya H, et al. Anatomical etiology of "pseudo-sciatica" from supelridarlcluneal nerve entrapment: a laboratory investigation. J Pain Res. 2017;10:2539-

2544442

45. 144Browle A, Harley C. Development of a biotensegrity focused therapy for the treat of pelvic organ prolapse: A retrospective case series. J Bodyw Mov Ther 2020; 24(1):4145-25.

46. 1446ozzi P, Bongiorno D, Vitturini C. Low back pain and kidney mobility: local ostebathic fascial manipulation decreases pain perception and improves renal mobility. J Bod,144/81 ov Ther 2012; 16(3): 381-91.

47. 144 Acevedo Jl, Beskin JL. Complications of plantar fascia rupture associated with cortikesforoid injection. Foot Ankle Int 1998; 19(2): 91-7.

48. 145Klingler W, Velders M, Hoppe K, Pedro M, Schleip R. Clinical relevance of fascial tissule45ad dysfunctions. Curr Pain Headache Rep 2014; 18(8): 439.

49. 145Bsieh YL, Kao MJ, Kuan TS, Chen SM, Chen JT, Hong CZ. Dry needling to a key myofA5C4al trigger point may reduce the irritability of satellite MTrPs. Am J Phys Med Rehalbi5.52007;86(5):397-403.

50. 145Quintner JL, Cohen ML. Referred pain of peripheral nerve origin: an alternative to the "Irafy fascial pain" construct. Clin J Pain 1994; 10(3): 243-51. 
51. 1458omasek JJ, Gabbiani G, Hinz B, Chaponnier C, Brown RA. Myofibroblasts and mechas-regulation of connective tissue remodelling. Nat Rev Mol Cell Biol 2002; 3(5): 349-

63. 1460

52. 146\$tempien-Otero A, Kim DH, Davis J. Molecular networks underlying myofibroblast fate 146ribrosis. J Mol Cell Cardiol 2016; 97: 153-61.

53. 146Biragoli M, Salvarani N, Rohr S. Myofibroblasts induce ectopic activity in cardiac tissule464rc Res. 2007;101(8):755-8

54. $146 \mathrm{~J}$ rits I, Charipova K, Gress K, et al. Treatment and management of myofascial pain syndrøáe. Best Pract Res Clin Anaesthesiol. 2020; 34(3):427-448.

55. 146Dommerholt J, Hooks T, Chou LW, Finnegan M. A critical overview of the current myofa€sal pain literature - January 2018. J Bodyw Mov Ther. 2018; 22(1):184-191.

56. 1469rguisuelas MD, Lisón JF, Sánchez-Zuriaga D, Martínez-Hurtado I, DoménechFern RandA̋̋Ized Clinical Trial. Spine (Phila Pa 1976). 2017;42(9):627-634.

57. 147 Dommerholt J, Thorp JN, Chou LW, Hooks T. A critical overview of the current myofAş3al pain literature - January 2020. J Bodyw Mov Ther 2020; 24(2): 213-24.

58. 147 hen JT, Chung KC, Hou CR, Kuan TS, Chen SM, Hong CZ. Inhibitory effect of dry needking on the spontaneous electrical activity recorded from myofascial trigger spots of rabbittal6eletal muscle. Am J Phys Med Rehabil 2001; 80(10): 729-35.

59. 147 Hughes EJ, McDermott K, Funk MF. Evaluation of hyaluronan content in areas of densfife8tion compared to adjacent areas of fascia. J Bodyw Mov Ther 2019; 23(2): 324-8.

60. 147 Castella LF, Buscemi L, Godbout C, Meister JJ, Hinz B. A new lock-step mechanism of matđiß8Qmodelling based on subcellular contractile events. J Cell Sci. 2010; 123(Pt 10):1751-

60. 1481 
61. 148Arora PD, Bibby KJ, McCulloch CA. Slow oscillations of free intracellular calcium ion condeftBation in human fibroblasts responding to mechanical stretch. J Cell Physiol 1994; 161(248187-200.

62. 148ฐangevin HM, Cornbrooks CJ, Taatjes DJ. Fibroblasts form a body-wide cellular netwa86 Histochem Cell Biol. 2004; 122(1):7-15.

63. 148Zembong J, Sabass B, Sun B, Rogers ME, Stone HA. Mechanics regulates ATPstim14 collective calcium response in fibroblast cells. J R Soc Interface. 2015; 12(108990150140.

64. 1490 Wolfson B, Zhang Y, Gernapudi R, et al. A High-Fat Diet Promotes Mammary Gland Myofihg $37(41.400461-16$.

65. 1493Nitt W, Buttner P, Jannasch A, Matschke K, Waldow T. Reversal of myofibroblastic activatin by polyunsaturated fatty acids in valvular interstitial cells from aortic valves. Role of RHAQД̧G-actin/MRTF signalling. J Mol Cell Cardiol 2014; 74: 127-38.

66. 1498u Q, Wang T, Zhou X, et al. WId(S) reduces paraquat-induced cytotoxicity via SIRT1 in nAAGReuronal cells by attenuating the depletion of NAD. PLoS One 2011; 6(7): e21770.

67. 1498ai W, Deng S, Wu W, et al. Rapamycin attenuates the paraquat-induced pulmonary fibrols499hrough activating Nrf2 pathway. J Cell Physiol 2020; 235(2): 1759-68.

68. 150ßarbe MF, Hilliard BA, Amin M, et al. Blocking CTGF/CCN2 reverses neural fibrosis and $\mathbf{5}$ E⿵冂orimotor declines in a rat model of overuse-induced median mononeuropathy. J OrthbipoRes. 2020; 38(11):2396-2408.

69. 150ßhen Y, Abraham DJ, Shi-Wen X, et al. CCN2 (connective tissue growth factor) promb0As fibroblast adhesion to fibronectin. Mol Biol Cell. 2004; 15(12):5635-46.

70. 1505 imms RW, Zerbini CA, Ferrante N, Anthony J, Felson DT, Craven DE. Fibromyalgia syndrbare in patients infected with human immunodeficiency virus. The Boston City Hospital Clini舐AIDS Team. Am J Med 1992; 92(4): 368-74. 
71. 150\&1ong F, Saiman Y, Si C, Mosoian A, Bansal MB. X4 Human immunodeficiency virus type15 $\$ 120$ promotes human hepatic stellate cell activation and collagen I expression throllegthanteractions with CXCR4. PLoS One. 2012;7(3):e33659.

72. 151Then TC, Chang SW, Wang TY. Moxifloxacin modifies corneal fibroblast-tomyofibzðblast differentiation. Br J Pharmacol 2013; 168(6): 1341-54.

73. 151ßanjizadeh-Zavareh S, Sodhi M, SpangehI T, Carleton B, Etminan M. Oral fluondsquffinolones and risk of fibromyalgia. Br J Clin Pharmacol 2019; 85(1): 236-9.

74. 1515quier CA. The effect of stretching on formation of myofibroblasts in mouse skin.

Cell TEşGGe Res 1981; 220(2): 325-35.

75. $151 \mathrm{G}$ offin JM, Pittet P, Csucs G, Lussi JW, Meister JJ, Hinz B. Focal adhesion size controls tensilon-8lependent recruitment of alpha-smooth muscle actin to stress fibers. J Cell Biol 2006;51182(2): 259-68.

76. 1520olphens M, Vansteelandt S, Cagnie B, Vleeming A, Nijs J, Vanderstraeten G,

Danđ̇ęlts L. Multivariable modeling of factors associated with spinal pain in young adoles2ance. Eur Spine J. 2016;25(9):2809-21.

77. 152 Kaergaard A, Andersen JH. Musculoskeletal disorders of the neck and shoulders in femalsestewing machine operators: prevalence, incidence, and prognosis. Occup Environ Med 2000;58B(8): 528-34.

78. 1526hen JC, Dennerlein JT, Chang CC, Chang WR, Christiani DC. Seat inclination, use of lumb52马upport and low-back pain of taxi drivers. Scand J Work Environ Health.

2005;321\$4):258-65.

79. 152昏alichman L, Lachman H, Freilich N. Long-term impact of ankle sprains on postural contr6Bend fascial densification. J Bodyw Mov Ther 2016; 20(4): 914-9.

80. 153Hinz B, Mastrangelo D, Iselin CE, Chaponnier C, Gabbiani G. Mechanical tension contr5B32granulation tissue contractile activity and myofibroblast differentiation. Am J Pathol 200115B39(3): 1009-20. 
81. 153Burton AR, Brown R, Macefield VG. Selective activation of muscle and skin

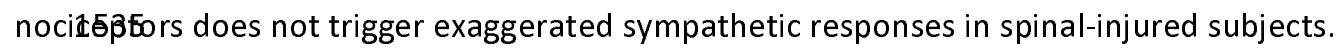
Spin 7566 rd. 2008; 46(10):660-5.

82. 1537moroso Borges BL, Bortolazzo GL, Neto HP. Effects of spinal manipulation and myof5s8al techniques on heart rate variability: A systematic review. J Bodyw Mov Ther 2018:5Bg(1): 203-8.

83. 1540linz B, Phan SH, Thannickal VJ, et al. Recent developments in myofibroblast biology: paradtighs for connective tissue remodeling. Am J Pathol 2012; 180(4): 1340-55.

84. 154Zoldenberg DL, Clauw DJ, Palmer RE, Clair AG. Opioid Use in Fibromyalgia: A Caut16Aary Tale. Mayo Clin Proc. 2016; 91(5):640-8.

85. 1544Niraj G, Alva S. Opioid Reduction and Long-Term Outcomes in Abdominal Myofascial Pain15545drome (AMPS): A 6-Year Longitudinal Prospective Audit of 207 Patients. Pain Phys15146. 2020;23(5):E441-E450.

86. 154Rico-Villademoros F, Postigo-Martin P, Garcia-Leiva JM, Ordoñez-Carrasco JL, Cala15148 EP. Patterns of pharmacologic and non-pharmacologic treatment, treatment satisf 549 on and perceived tolerability in patients with fibromyalgia: a patients' survey. Clin Exp RБ50matol 2020; 38 Suppl 123(1): 72-8.

87. 155Frost FA, Jessen B, Siggaard-Andersen J. A control, double-blind comparison of mep15daine injection versus saline injection for myofascial pain. Lancet 1980; 1(8167): 499500.1553

88. 1554angevin HM, Churchill DL, Cipolla MJ. Mechanical signaling through connective tissuk5 55 mechanism for the therapeutic effect of acupuncture. FASEB J. 2001;15(12):2275-

82. 1556

89. 155Zangevin HM, Churchill DL, Fox JR, Badger GJ, Garra BS, Krag MH. Biomechanical resp\$558 to acupuncture needling in humans. J Appl Physiol (1985) 2001; 91(6): 2471-8. 
90. 1559omasek JJ, Haaksma CJ, Eddy RJ, Vaughan MB. Fibroblast contraction occurs on release6 6 f tension in attached collagen lattices: dependency on an organized actin cyto15elleton and serum. Anat Rec 1992; 232(3): 359-68.

91. 156Fox JR, Gray W, Koptiuch C, Badger GJ, Langevin HM. Anisotropic tissue motion indurE63by acupuncture needling along intermuscular connective tissue planes. J Altern CompB6Aent Med. 2014;20(4):290-4.

92. 156Ernberg $M$, Hedenberg-Magnusson B, Alstergren $P$, Kopp $S$. The level of serotonin in the 145 fricial masseter muscle in relation to local pain and allodynia. Life Sci 1999; 65(3):

$313-2567$

93. $156 \$$ Moraska AF, Hickner RC, Kohrt WM, Brewer A. Changes in blood flow and cellular metâ569sm at a myofascial trigger point with trigger point release (ischemic compression): a prodf50Đprinciple pilot study. Arch Phys Med Rehabil. 2013;94(1):196-200.

94. 157 Kural MH, Billiar KL. Myofibroblast persistence with real-time changes in boundary stiffi18\$32 Acta Biomater 2016; 32: 223-30.

95. 1573ánchez-Infante J, Bravo-Sánchez A, Jiménez F, Abián-Vicén J. Effects of Dry Needling on MEgAle Stiffness in Latent Myofascial Trigger Points: A Randomized Controlled Trial. J

Pain18081: S1526-5900(21)00024-9

96. 157 Maher RM, Hayes DM, Shinohara M. Quantification of dry needling and posture effedt570n myofascial trigger points using ultrasound shear-wave elastography. Arch Phys MedlBeBBabil. 2013;94(11):2146-50.

97. 157quan S, Zhu ZM, Ruan JL, et al. Randomized Trial on Comparison of the Efficacy of Extrå\&poreal Shock Wave Therapy and Dry Needling in Myofascial Trigger Points. Am J PhyslbBed Rehabil 2019; 98(8): 677-84.

98. 158https://www.youtube.com/watch?v=uzy8-

$w Q z$ TH\&IY\&t=3s\&ab_channel=RonelleWood 
medRxiv preprint doi: https://doi.org/10.1101/2021.07.06.21260111; this version posted August 29, 2021. The copyright holder for this preprint (which was not certified by peer review) is the author/funder, who has granted medRxiv a license to display the preprint in perpetuity.

All rights reserved. No reuse allowed without permission.

Microssopic view of the dynamic fiber network. Force vectors travel according to the comp\$8s architecture.

99. 1586

http\$5/\$www.youtube.com/watch?v=cqHtEtZ9mRQ\&t=177s\&ab channel=MedFreelancers

2:5913 top left - fascia tears without diathermy touching it under low forces, or manip8pation in areas adjacent to it.

100.159Qttps://www.youtube.com/watch?v=3u0his53IMU\&ab channel=JeffreyChua

Needfeslvibrate when inserted. Some seem to be moved by horizontal force vectors.

PattĐ̄อ̨ of vibration change as a function of time. It seems some groups of needles vibrate togetbę. Overall a complex dynamic behavior is observed.

101.159 \$ttps://www.youtube.com/watch?v=eWOlvOVKDxE\&ab channel=UKyOrtho

102.159ฐi ADR, Putra KB, Chen L, Montgomery JS, Shih A. Mosquito proboscis-inspired needls96sertion to reduce tissue deformation and organ displacement. Sci Rep. 2020;

10(1151927248.

103.1598i ADR, Liu Y, Plott J, Chen L, Montgomery JS, Shih A. Multi-Bevel Needle Design

Enablag Accurate Insertion in Biopsy for Cancer Diagnosis. IEEE Trans Biomed Eng.

2021,685):1477-1486.

104.1601angevin HM, Konofagou EE, Badger GJ, Churchill DL, Fox JR, Ophir J, Garra BS. Tissue displements during acupuncture using ultrasound elastography techniques. Ultrasound Med1Bn3. 2004;30(9):1173-83.

105.1604angevin HM, Churchill DL, Wu J, et al. Evidence of connective tissue involvement in acupltgosture. FASEB J. 2002; 16(8):872-4.

106.1606oreide E, Murad MH, Denbeigh JM, et al. Treatment of Dupuytren's contracture: a systaficic review. Bone Joint J 2018; 100-B(9): 1138-45. 
107.160\$oog P, Buchner L, Cerny MK, Schmauss D, Megerle K, Erne H. Analysis of recur6egce and complications after percutaneous needle fasciotomy in Dupuytren's disease. Arch101thop Trauma Surg 2019; 139(10): 1471-7.

108.161\$ellman JR. Plantar fascia rupture associated with corticosteroid injection. Foot Anklediz 1994; 15(7): 376-81.

109.1613Nu L. Nonlinear finite element analysis for musculoskeletal biomechanics of medial and 1atal plantar longitudinal arch of Virtual Chinese Human after plantar ligamentous strudtirira failures. Clin Biomech (Bristol, Avon). 2007; 22(2):221-9.

110.1616lettrich CM, DiCarlo EF, Faryniarz D, Vadasdi KB, Williams R, Hannafin JA. The effect of mifofibroblasts and corticosteroid injections in adhesive capsulitis. J Shoulder Elbow Surg. 2016,618(8):1274-9.

111.1619anjuan-Cervero R, Carrera-Hueso FJ, Vazquez-Ferreiro P, Gomez-Herrero D. Adverse Effediszof Collagenase in the Treatment of Dupuytren Disease: A Systematic Review. BioDrGig1 2017; 31(2): 105-15.

112.162 Rin FY, Manrique OJ, Lin CL, Cheng HT. Incidence of trigger digits following carpal tunnle623lease: A nationwide, population-based retrospective cohort study. Medicine (Baltíroore). 2017;96(27):e7355.

113.162 Acar MA, Kütahya H, Güleç A, Elmadağ M, Karalezli N, Ogun TC. Triggering of the Digitb62f(fer Carpal Tunnel Surgery. Ann Plast Surg. 2015;75(4):393-7.

114.162Mishra AK, Skrepnik NV, Edwards SG, et al. Efficacy of platelet-rich plasma for chroh62\&ennis elbow: a double-blind, prospective, multicenter, randomized controlled trial of 236 16 tients. Am J Sports Med 2014; 42(2): 463-71.

115.1636rottlieb NL, Riskin WG. Complications of local corticosteroid injections. JAMA 1980; 243(116931547-8. 
116.1638totts AK, Carroll KL, Schafer PG, Santora SD, Branigan TD. Medial compartment syndr6Bße of the foot: an unusual complication of spine surgery. Spine (Phila Pa 1976) 2003; 28(6)6B118-20.

117.163\$ierau D, Cassidy JD, Yong-Hing K. Low-back pain and straight leg raising in children and zбъ6escents. Spine (Phila Pa 1976). 1989;14(5):526-8.

118.1637assaux M, Milan JL. Stem cell mechanical behaviour modelling: substrate's curvæ638e influence during adhesion. Biomech Model Mechanobiol. 2017;16(4):1295-1308. 119.1639lindman B, Ma Q. Carbon nanotubes and crystalline silica induce matrix remodeling and t6A0raction by stimulating myofibroblast transformation in a three-dimensional culture of hưfen pulmonary fibroblasts: role of dimension and rigidity. Arch Toxicol.

2018,0\&\11):3291-3305.

120.164ßmris K, Jespersen A, Bliddal H. Self-reported somatosensory symptoms of neurbathic pain in fibromyalgia and chronic widespread pain correlate with tender point countt6arsd pressure-pain thresholds. Pain 2010; 151(3): 664-9.

121.164Bordoni B, Bordoni G. Reflections on osteopathic fascia treatment in the peripheral nervbeflsystem. J Pain Res 2015; 8: 735-40.

122.164\$etersen MW, Schroder A, Jorgensen T, et al. Irritable bowel, chronic widespread pain16480nic fatigue and related syndromes are prevalent and highly overlapping in the gener6\$population: DanFunD. Sci Rep 2020; 10(1): 3273.

123.165Treed F. A review of the incidence and risk factors for fibromyalgia and chronic widesfpread pain in population-based studies. Pain 2020; 161(6): 1169-76.

124.165 Kalyan-Raman UP, Kalyan-Raman K, Yunus MB, Masi AT. Muscle pathology in primkafyibromyalgia syndrome: a light microscopic, histochemical and ultrastructural study. J Rhä6565atol 1984; 11(6): 808-13.

125.1656prott H, Salemi S, Gay RE, et al. Increased DNA fragmentation and ultrastructural chanifges7ın fibromyalgic muscle fibres. Ann Rheum Dis 2004; 63(3): 245-51. 
medRxiv preprint doi: https://doi.org/10.1101/2021.07.06.21260111; this version posted August 29, 2021. The copyright holder for this preprint (which was not certified by peer review) is the author/funder, who has granted medRxiv a license to display the preprint in perpetuity.

All rights reserved. No reuse allowed without permission.

126.165 Ivin A, Siösteen AK, Nilsson A, Kosek E. Decreased muscle blood flow in fibromyalgia patie1659during standardised muscle exercise: a contrast media enhanced colour Doppler study660r J Pain. 2006;10(2):137-44.

127.166Zdebik N, Zdebik A, Boguslawska J, Przezdziecka-Dolyk J, Turno-Krecicka A. Fibrafrgalgia syndrome and the eye-A review. Surv Ophthalmol 2021; 66(1): 132-7. 128.166 Morf S, Amann-Vesti B, Forster A, et al. Microcirculation abnormalities in patients with1f6160myalgia - measured by capillary microscopy and laser fluxmetry. Arthritis Res Ther 2005,66(2): R209-16.

129.1666rassi W, Core P, Carlino G, Salaffi F, Cervini C. Capillary permeability in fibromyalgia. J Rhê66ratol 1994; 21(7): 1328-31.

130.166๕vvdokimov D, Kreß L, Dinkel P, Frank J, Sommer C, Üçeyler N. Pain-associated Med16 6ors and Axon Pathfinders in Fibromyalgia Skin Cells. J Rheumatol. 2020;47(1):140148.1670

131.167 Wachter KC, Kaeser HE, Gühring H, Ettlin TM, Mennet P, Müller W. Muscle damping mea\$6קed with a modified pendulum test in patients with fibromyalgia, lumbago, and cervilcat 3yndrome. Spine (Phila Pa 1976). 1996;21(18):2137-42.

132.1674tolman AJ. Positional cervical spinal cord compression and fibromyalgia: a novel comb6186dity with important diagnostic and treatment implications. J Pain. 2008;9(7):613-22. 133.1676hang Y, Gurley K, Symons B, et al. Noninvasive optical characterization of muscle blooß6flठw, oxygenation, and metabolism in women with fibromyalgia. Arthritis Res Ther. 2011,67\$6):R236.

134.167 Bengtsson A, Henriksson KG, Larsson J. Muscle biopsy in primary fibromyalgia. Lightmicrbs80pical and histochemical findings. Scand J Rheumatol. 1986;15(1):1-6.

135.168Ihen WT, Yu CH, Sun CW. Altered near-infrared spectroscopy response to breathhold1682 ph patients with fibromyalgia. J Biophotonics. 2019;12(1):e201800142. 
136.168 Bengtsson A, Henriksson KG, Larsson J. Reduced high-energy phosphate levels in the painf6Bmuscles of patients with primary fibromyalgia. Arthritis Rheum 1986; 29(7): 817-21.

137.168Eiregia F, Giacomelli C, Giusti L, et al. Putative salivary biomarkers useful to differ686iate patients with fibromyalgia. J Proteomics 2019; 190: 44-54.

138.1688ikdar S, Shah JP, Gebreab T, Yen RH, Gilliams E, Danoff J, Gerber LH. Novel appli68 68 ns of ultrasound technology to visualize and characterize myofascial trigger points and 168Bounding soft tissue. Arch Phys Med Rehabil 2009; 90(11): 1829-38.

139.1690Misono S, Dietrich M, Piccirillo JF. The Puzzle of Medically Unexplained Symptoms-A Holist160View of the Patient With Laryngeal Symptoms. JAMA Otolaryngol Head Neck Surg. 2020692 1;146(6):550-551.

140.169Baekawa K, Clark GT, Kuboki T. Intramuscular hypoperfusion, adrenergic receptors, and 169Anic muscle pain. J Pain 2002; 3(4): 251-60.

141.1695ुold AR, Dipalo F, Gold MS, Broderick J. Inspiratory airflow dynamics during sleep in won1696vith fibromyalgia. Sleep. 2004;27(3):459-66.

142.169 Grabowski PJ, Slane LC, Thelen DG, Obermire T, Lee KS. Evidence of Generalized Must698tiffness in the Presence of Latent Trigger Points Within Infraspinatus. Arch Phys Med1Be日abil. 2018;99(11):2257-2262.

143.170đho KI, Lee JH, Kim SM, Lee HG, Kim TI. Assessment of endothelial function in

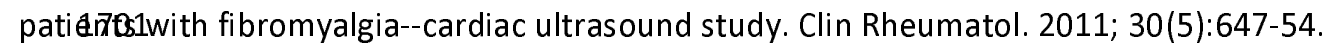
144.170オriantafyllias K, Stortz M, de Blasi M, Leistner C, Weinmann-Menke J, Schwarting A. Increased aortic stiffness in patients with fibromyalgia: results of a prospective study on carotidoffemoral pulse wave velocity. Clin Exp Rheumatol. 2019; 37 Suppl 116(1):114-115. 145.170Katz RS, Leavitt F, Small AK, Small BJ. Intramuscular Pressure is Almost Three Times High飞飞06 Fibromyalgia Patients: A Possible Mechanism for Understanding the Muscle Pain and TEQderness. J Rheumatol. 2020:jrheum.191068. 
medRxiv preprint doi: https://doi.org/10.1101/2021.07.06.21260111; this version posted August 29, 2021. The copyright holder for this preprint (which was not certified by peer review) is the author/funder, who has granted medRxiv a license to display the preprint in perpetuity.

All rights reserved. No reuse allowed without permission.

146.1708 ostanzo, L. S. (2018). Physiology (Sixth edition.). Philadelphia, PA: Elsevier. Pages $128-11209$

147.171ஞeerdle B, Söderberg K, Salvador Puigvert L, Rosendal L, Larsson B. Increased intedsfitilal concentrations of pyruvate and lactate in the trapezius muscle of patients with fibrởñłal|gia: a microdialysis study. J Rehabil Med. 2010;42(7):679-87.

148.171 Mclver KL, Evans C, Kraus RM, Ispas L, Sciotti VM, Hickner RC. NO-mediated alterazilibhs in skeletal muscle nutritive blood flow and lactate metabolism in fibromyalgia. Pain120B6;120(1-2):161-169.

149.1716an Tilburg MAL, Parisien M, Boles RG, Drury GL, Smith-Voudouris J, Verma V, Khoū718, Chabot-Doré AJ, Nackley AG, Smith SB, Whitehead WE, Zolnoun DA, Slade GD, TchiqRera I, Maixner W, Diatchenko L. A genetic polymorphism that is associated with mitokhbondrial energy metabolism increases risk of fibromyalgia. Pain. 2020;161(12):28602871720

150.172 Efrati S, Golan H, Bechor Y, Faran Y, Daphna-Tekoah S, Sekler G, Fishlev G, Ablin JN, Bergbin2D, Volkov O, Friedman M, Ben-Jacob E, Buskila D. Hyperbaric oxygen therapy can dimin7słBfibromyalgia syndrome--prospective clinical trial. PLoS One. 2015;10(5):e0127012 151.172 iampi de Andrade D, Maschietto M, Galhardoni R, Gouveia G, Chile T, Victorino KrepigAt AC, Dale CS, Brunoni AR, Parravano DC, Cueva Moscoso AS, Raicher I, Kaziyama HHS,17ęxeira MJ, Brentani HP. Epigenetics insights into chronic pain: DNA hypomethylation in filaroß̄̄yalgia-a controlled pilot-study. Pain. 2017;158(8):1473-1480.

152.172\$erez-Ruiz F, Calabozo M, Alonso-Ruiz A, Herrero A, Ruiz-Lucea E, Otermin I. High preva7age of undetected carpal tunnel syndrome in patients with fibromyalgia syndrome. J Rheüräol. 1995; 22(3):501-4.

153.173Bennett RM, Jones J, Turk DC, Russell IJ, Matallana L. An internet survey of 2,596 people3खith fibromyalgia. BMC Musculoskelet Disord. 2007; 8:27. 
medRxiv preprint doi: https://doi.org/10.1101/2021.07.06.21260111; this version posted August 29, 2021. The copyright holder for this preprint (which was not certified by peer review) is the author/funder, who has granted medRxiv a license to display the preprint in perpetuity.

All rights reserved. No reuse allowed without permission.

154.173 Æirestein GS, Kelley WN. Kelley's textbook of rheumatology. 9th ed. Philadelphia, PA: ElsevießßASaunders; 2013. Pages 733-750.

155.1735ugawara O, Atsuta Y, Iwahara T, Muramoto T, Watakabe M, Takemitsu Y. The effedtz36f mechanical compression and hypoxia on nerve root and dorsal root ganglia. An analұzJ37bf ectopic firing using an in vitro model. Spine (Phila Pa 1976). 1996; 21(18):2089-

94. 1738

156.1739ong XJ, Hu SJ, Greenquist KW, Zhang JM, LaMotte RH. Mechanical and thermal hyperatgesia and ectopic neuronal discharge after chronic compression of dorsal root gangl|za11 Neurophysiol. 1999; 82(6):3347-58.

157.174tGotoh H, Takahashi A. Mechanical stimuli induce intracellular calcium response in a subplophlalation of cultured rat sensory neurons. Neuroscience. 1999; 92(4):1323-9. 158.1744ladman SJ, Ward RE, Michael-Titus AT, Knight MM, Priestley JV. The effect of mechżAfsal strain or hypoxia on cell death in subpopulations of rat dorsal root ganglion neurb7 7 G6in vitro. Neuroscience. 2010; 171(2):577-87.

159.174 XNang JC, Sung FC, Men M, Wang KA, Lin CL, Kao CH. Bidirectional association betweA8 fibromyalgia and gastroesophageal reflux disease: two population-based retrdsßative cohort analysis. Pain. 2017; 158(10):1971-1978 160.1750athan H. Osteophytes of the spine compressing the sympathetic trunk and splañ $\bar{d}$ (50ic nerves in the thorax. Spine (Phila Pa 1976). 1987; 12(6):527-32 161.175\&Neinberg H, Nathan H, Magora F, Robin GC, Aviad I. Arthritis of the first

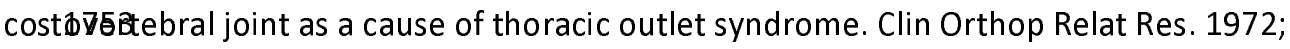
$86: 158563$.

162.1755Nolfe F, Rasker JJ, Häuser W. Hearing loss in fibromyalgia? Somatic sensory and non-kē5/sory symptoms in patients with fibromyalgia and other rheumatic disorders. Clin Exp Rheüntatol. 2012; 30(6 Suppl 74):88-93 
medRxiv preprint doi: https://doi.org/10.1101/2021.07.06.21260111; this version posted August 29, 2021. The copyright holder for this preprint (which was not certified by peer review) is the author/funder, who has granted medRxiv a license to display the preprint in perpetuity.

All rights reserved. No reuse allowed without permission.

163.175\%vdokimov D, Frank J, Klitsch A, et al. Reduction of skin innervation is associated with1尹̈50vere fibromyalgia phenotype. Ann Neurol. 2019; 86(4):504-516.

164.1760tttps://www.uptodate.com/contents/clinical-manifestations-and-diagnosis-of-

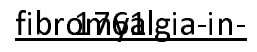

adults.6search=fibrommyalgia\&source=search result\&selectedTitle=1 150\&usage type=def ault\&đ6splay rank=1 By Don L Goldenberg, accessed March 2021.

165.176 Raphael KG, Marbach JJ. Comorbid fibromyalgia accounts for reduced fecundity in wonder65ith myofascial face pain. Clin J Pain 2000; 16(1): 29-36.

166.176\$ancuso AC, Summers KM, Mengeling MA, Torner JC, Ryan GL, Sadler AG. Infertility and HeGlth-Related Quality of Life in United States Women Veterans. J Womens Health (Lard776\%) 2020; 29(3): 412-9.

167.176甲iersiala K, Akst LM, Hillel AT, Best SR. Chronic Pain Syndromes and Their Laryngeal Manifeztlations. JAMA Otolaryngol Head Neck Surg. 2020; 146(6):543-549.

168.1771 Vaeroy H, Helle R, Forre O, Kass E, Terenius L. Elevated CSF levels of substance P and highliñedence of Raynaud phenomenon in patients with fibromyalgia: new features for

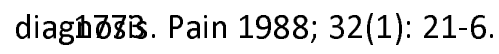

169.177\$imms RW, Zerbini CA, Ferrante N, Anthony J, Felson DT, Craven DE. Fibromyalgia syndron̄5e in patients infected with human immunodeficiency virus. The Boston City Hospital Cliniða7AIDS Team. Am J Med. 1992;92(4):368-74.

170.177 Tlark S, Tindall E, Bennett RM. A double blind crossover trial of prednisone versus

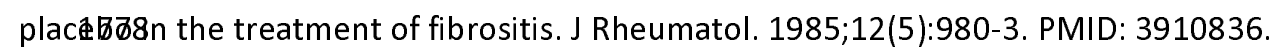

171.177\$asi DL, Velly AM, Schiffman EL, Lenton PA, Besspiata DA, Rankin AM, Hughes PJ, Swif1780KehI L. Human temporomandibular joint and myofascial pain biochemical profiles: a casA81ntrol study. J Oral Rehabil. 2012;39(5):326-37.

172.178 Grosman-Rimon L, Parkinson W, Upadhye S, et al. Circulating biomarkers in acute myofä83al pain: A case-control study. Medicine (Baltimore) 2016; 95(37): e4650. 
173.1784liddam DM, Lee SH, Su YT, Chan RC. Brain structural changes in patients with chroh785nyofascial pain. Eur J Pain. 2017;21(1):148-158.

174.1786amírez-Tejero JA, Martínez-Lara E, Peinado MÁ, Del Moral ML, Siles E. Hyd đä8/7yrosol as a Promising Ally in the Treatment of Fibromyalgia. Nutrients. 2020;018\$8):2386.

175.1789taud R. Peripheral pain mechanisms in chronic widespread pain. Best Pract Res Clin Rhedreal. 2011;25(2):155-64.

176.179 \$acheti A, Szemere J, Bernstein B, Tafas T, Schechter N, Tsipouras P. Chronic pain is a man1fegzation of the Ehlers-Danlos syndrome. J Pain Symptom Manage. 1997;14(2):88-93. 177.179ßacasuso-Díaz M, Collantes-Estévez E. Joint hypermobility in patients with

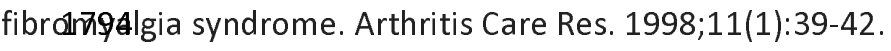

178.179goppi N, Chiarelli N, Binetti S, Ritelli M, Colombi M. Dermal fibroblast-tomyofiB 96 blast transition sustained by $\alpha$ vß3 integrin-ILK-Snail1/Slug signaling is a common

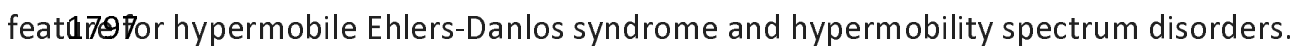
Bioc\$7988Biophys Acta Mol Basis Dis. 2018;1864(4 Pt A):1010-1023.

179.179@hiarelli N, Zoppi N, Ritelli M, et al. Biological insights in the pathogenesis of hyper800bile Ehlers-Danlos syndrome from proteome profiling of patients' dermal myof

180.1808eo BR, Chen X, Ling L, et al. Collagen microarchitecture mechanically controls myofBoBblast differentiation. Proc Natl Acad Sci U S A. 2020;117(21):11387-11398.

181.1804ostine M, Davis F, Roberts BA, Risko R, Asmus M, Cappelleri JC, Sadosky A. Clinical Chareferistics of Fibromyalgia in a Chronic Pain Population. Pain Pract. 2018;18(1):67-78. 182.1806upta A, McBeth J, Macfarlane GJ, et al. Pressure pain thresholds and tender point coun 180 Bs predictors of new chronic widespread pain in somatising subjects. Ann Rheum Dis. 2007808(4):517-21. 
medRxiv preprint doi: https://doi.org/10.1101/2021.07.06.21260111; this version posted August 29, 2021. The copyright holder for this preprint (which was not certified by peer review) is the author/funder, who has granted medRxiv a license to display the preprint in perpetuity.

All rights reserved. No reuse allowed without permission.

183.180qhen JY, Newcomb B, Zhou C, et al. Tricyclic Antidepressants Promote Ceramide Accurlituation to Regulate Collagen Production in Human Hepatic Stellate Cells. Sci Rep.

2011,81:14867

184.181Morrissey JJ. Pleiotropic effects of amitriptyline ameliorate renal fibrosis. Kidney Int. 2009873(6):583-4

185.1810lianas MC, Dedoni S, Onali P. Antidepressants induce profibrotic responses via the lysopßBđ5phatidic acid receptor LPA1. Eur J Pharmacol. 2020;873:172963.

186.181Bruno R, Galastri S, Sacchi P, et al. gp120 modulates the biology of human hepatic stellåđđells: a link between HIV infection and liver fibrogenesis. Gut. 2010;59(4):513-20. 187.1818berer E, Surtov-Pudar M, Wilfinger D, Deutsch A, Leitinger G, Schaider H. Co-culture of hubiten fibroblasts and Borrelia burgdorferi enhances collagen and growth factor mRNA. Arch18zomatol Res. 2018;310(2):117-126.

188.1821 nudurthi SD, Luthra P, Bose RJC, McCarthy JR, Kontaridis MI. Cardiac inflammation in CO8D2-19: Lessons from heart failure. Life Sci. 2020;260:118482.

189.182 Rruglikov IL, Scherer PE. The Role of Adipocytes and Adipocyte-Like Cells in the Severłz/4tof COVID-19 Infections. Obesity (Silver Spring). 2020;28(7):1187-1190.

190.182Russell IJ, Vaeroy H, Javors M, Nyberg F. Cerebrospinal fluid biogenic amine metåabtes in fibromyalgia/fibrositis syndrome and rheumatoid arthritis. Arthritis Rheum 1991/835(5): 550-6.

191.182\&lcaino C, Knutson KR, Treichel AJ, et al. A population of gut epithelial enter82Gromaffin cells is mechanosensitive and requires Piezo2 to convert force into sero1830 release. Proc Natl Acad Sci U S A. 2018;115(32):E7632-E7641.

192.183Pan J, Copland I, Post M, Yeger H, Cutz E. Mechanical stretch-induced serotonin releAse3trom pulmonary neuroendocrine cells: implications for lung development. Am J Phys18BBung Cell Mol Physiol. 2006;290(1):L185-93. 
medRxiv preprint doi: https://doi.org/10.1101/2021.07.06.21260111; this version posted August 29, 2021. The copyright holder for this preprint (which was not certified by peer review) is the author/funder, who has granted medRxiv a license to display the preprint in perpetuity.

All rights reserved. No reuse allowed without permission.

193.183Dolivo DM, Larson SA, Dominko T. Tryptophan metabolites kynurenine and sero1836n regulate fibroblast activation and fibrosis. Cell Mol Life Sci 2018; 75(20): 3663-81.

194.1838tunes AK, Reseland JE, Hauso O, et al. Adipocytes express a functional system for sero18B8 synthesis, reuptake and receptor activation. Diabetes Obes Metab 2011;13(6): 551-8839

195.1840aschko G, Hepp U, Berkhoff M, Schmet M, Michel BA, Gay S, Sprott H. Serum sero18Ain levels are not useful in diagnosing fibromyalgia. Ann Rheum Dis. 2007;66(9):1267-

$8 \quad 1842$

196.184Begangneux E, Mora JJ, Spreux-Varoquaux O, et al. Cerebrospinal fluid biogenic ami18 8 tabolites, plasma-rich platelet serotonin and $[3 \mathrm{H}]$ imipramine reuptake in the prim²45ibromyalgia syndrome. Rheumatology (Oxford). 2001;40(3):290-6.

197.184Gussell IJ, Michalek JE, Vipraio GA, Fletcher EM, Javors MA, Bowden CA. Platelet 3Himipr8Ānne uptake receptor density and serum serotonin levels in patients with fibro1848|gia/fibrositis syndrome. J Rheumatol. 1992 Jan;19(1):104-9. PMID: 1313504. 198.184Groven N, Reitan SK, Fors EA, Guzey IC. Kynurenine metabolites and ratios differ betw850 Chronic Fatigue Syndrome, Fibromyalgia, and healthy controls.

Psych8fneuroendocrinology. 2021;131:105287.

199.185Barjandi G, Louca Jounger S, Löfgren M, Bileviciute-Ljungar I, Kosek E, Ernberg M. Plasifestryptophan and kynurenine in females with temporomandibular disorders and fibrorbalgia-An exploratory pilot study. J Oral Rehabil. 2020;47(2):150-157.

200.185Russell IJ, Vipraio GA, Morgan WW, Bowden CL. Is there a metabolic basis for the fibrol885 syndrome? Am J Med. 1986;81(3A):50-4

201.1857unus MB, Dailey JW, Aldag JC, Masi AT, Jobe PC. Plasma tryptophan and other amir8 8 8.ids in primary fibromyalgia: a controlled study. J Rheumatol 1992; 19(1): 90-4.

202.1859aber AA, Boros MJ, Mancl T, Elgamal MH, Song S, Wisadrattanapong T. The effect of lapa18seopic Roux-en-Y gastric bypass on fibromyalgia. Obes Surg 2008; 18(6): 652-5. 
203.186Adkisson CD, Yip L, Armstrong MJ, Stang MT, Carty SE, McCoy KL. Fibromyalgia sym $\$ 862$ s and medication requirements respond to parathyroidectomy. Surgery. 2014; 156(6961614-20; discussion 1620-1.

204.186 Raftopoulos Y, Papasavas P, Landreneau R, et al. Clinical outcome of laparoscopic antineffa5x surgery for patients with irritable bowel syndrome. Surg Endosc. 2004; 18(4):655-

9. 1866

205.186 WNu MC, Ma KS, Wang YH, Wei JC. Impact of tonsillectomy on irritable bowel syndr868e: A nationwide population-based cohort study. PLoS One. 2020; 15(9):e0238242. 206.186 Rosen JM, Adams PN, Saps M. Umbilical hernia repair increases the rate of functBßRI gastrointestinal disorders in children. J Pediatr. 2013; 163(4):1065-8. 207.1871 Yang CY, Wu MC, Lin MC, Wei JC. Risk of irritable bowel syndrome in patients who undeBsent appendectomy: A nationwide population-based cohort study. EClinicalMedicine. 2020873:100383.

208.1874/incent A, Whipple MO, Luedtke CA, et al. Pain and other symptom severity in won1875with fibromyalgia and a previous hysterectomy. J Pain Res. 2011; 4:325-9. 209.187\&/leeming A, Schuenke MD, Danneels L, Willard FH. The functional coupling of the deep\$bdominal and paraspinal muscles: the effects of simulated paraspinal muscle contr8 8 Bon on force transfer to the middle and posterior layer of the thoracolumbar fascia. J Anatl82014; 225(4):447-62.

210.1880Marcelin G, Silveira ALM, Martins LB, Ferreira AV, Clément K. Deciphering the cellu18Binterplays underlying obesity-induced adipose tissue fibrosis. J Clin Invest. 2019; $129(1188924032-4040$.

211.188Bkifuji A, Turk DC. Sex hormones and pain in regularly menstruating women with fibro18\&Algia syndrome. J Pain 2006; 7(11): 851-9.

212.1885 $\mathrm{Nu}$ M, Han M, Li J, et al. 17beta-estradiol inhibits angiotensin Il-induced cardiac myof 886 blast differentiation. Eur J Pharmacol. 2009; 616(1-3):155-9. 
medRxiv preprint doi: https://doi.org/10.1101/2021.07.06.21260111; this version posted August 29, 2021. The copyright holder for this preprint (which was not certified by peer review) is the author/funder, who has granted medRxiv a license to display the preprint in perpetuity.

All rights reserved. No reuse allowed without permission.

213.188 1g MM, Stafford SJ, Mateus M, et al. Phosphodiesterase Type 5 Inhibitors and Seleđ888 Estrogen Receptor Modulators Can Prevent But Not Reverse Myofibroblast

Tran1588mation in Peyronie's Disease. J Sex Med. 2020; 17(10):1848-1864.

214.189đarthy JM, Sundqvist A, Heldin A et al. Tamoxifen Inhibits TGF- $\beta$-Mediated Activation of Masfiblbroblasts by Blocking Non-Smad Signaling Through ERK1/2. J Cell Physiol.

2015890(12):3084-92.

215.1893iang HS, Zhu LL, Zhang Z, Chen H, Chen Y, Dai YT. Estradiol attenuates the TGF- $\beta 1$ indur\$4 $\$$ conversion of primary TAFs into myofibroblasts and inhibits collagen production and myof 8 5blast contraction by modulating the Smad and Rho/ROCK signaling pathways. Int J Mol1986. 2015; 36(3):801-7.

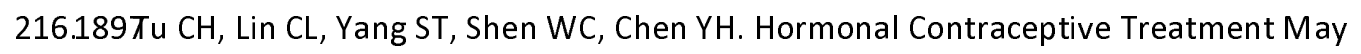
Red18@8he Risk of Fibromyalgia in Women with Dysmenorrhea: A Cohort Study. J Pers Med. $2020,890(4): 280$.

217.190Blümel JE, Palacios S, Legorreta D, Vallejo MS, Sarra S. Is fibromyalgia part of the climatereric syndrome? Maturitas. 2012; 73(2):87-93.

218.190Ramirez-Moreno JM, Ceberino D, Gonzalez Plata A, et al. Mask-associated 'de novo' head 40 in in healthcare workers during the COVID-19 pandemic. Occup Environ Med. 2020; oemesta20-106956.

219.190" im EC, Seet RC, Lee KH, Wilder-Smith EP, Chuah BY, Ong BK. Headaches and the N95 face196k amongst healthcare providers. Acta Neurol Scand. 2006; 113(3):199-202.

220.190Blau JN. Ponytail headache: a pure extracranial headache. Headache 2004; 44(5):

411-B908

221.190Ansari HN, Solomon GD. Hijab (headscarf) headache. Headache 2015; 55(3): 437-8.

222.1910ane A. Bra strap headache. Med J Aust. 1983; 1(4):155.

223.191Balfour W. Observations on the Pathology and Cure of Rheumatism. Edinb Med Surg J. 18119121(42):168-187. 
medRxiv preprint doi: https://doi.org/10.1101/2021.07.06.21260111; this version posted August 29, 2021. The copyright holder for this preprint (which was not certified by peer review) is the author/funder, who has granted medRxiv a license to display the preprint in perpetuity.

All rights reserved. No reuse allowed without permission.

224.191Bardin L, Malfetes N, Newman-Tancredi A, Depoortere R. Chronic restraint stress indurequechanical and cold allodynia, and enhances inflammatory pain in rat: Relevance to humber15tress-associated painful pathologies. Behav Brain Res 2009; 205(2): 360-6.

225.1916hiba S, Numakawa T, Ninomiya M, Richards MC, Wakabayashi C, Kunugi H. Chronic restrłañ stress causes anxiety- and depression-like behaviors, downregulates glucocorticoid

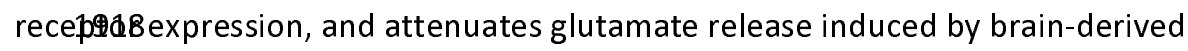
neurlot:日phic factor in the prefrontal cortex. Prog Neuropsychopharmacol Biol Psychiatry $2012,939)(1): 112-9$

226.192Farhin S, Wong A, Delungahawatta T, et al. Restraint stress induced gut dysmotility is dimißosłzed by a milk oligosaccharide (2'-fucosyllactose) in vitro. PLoS One 2019; 14(4): e02119D31.

227.192\$ugama S, Sekiyama K, Kodama T, et al. Chronic restraint stress triggers dopånמEergic and noradrenergic neurodegeneration: Possible role of chronic stress in the onselt92f6Parkinson's disease. Brain Behav Immun 2016; 51: 39-46.

228.1928pyrka J, Hess G. Repeated Neck Restraint Stress Bidirectionally Modulates Excitat38y Transmission in the Dentate Gyrus and Performance in a Hippocampus-dependent Men1929Task. Neuroscience 2018; 379: 32-44.

229.1930angevin HM, Stevens-Tuttle D, Fox JR, Badger GJ, Bouffard NA, Krag MH, Wu J, Henis9M. Ultrasound evidence of altered lumbar connective tissue structure in human subjథ日eß2with chronic low back pain. BMC Musculoskelet Disord. 2009;10:151.

230.193Jaş S, Korkusuz F, Erden Z. Neck Muscle Stiffness in Participants With and Without Chrớlg34Neck Pain: A Shear-Wave Elastography Study. J Manipulative Physiol Ther. 2018; 41(7195850-588.

231.1936astro Sánchez AM, García López H, Fernández Sánchez M, et al. Improvement in clinid8Bठ̈utcomes after dry needling versus myofascial release on pain pressure thresholds, 
medRxiv preprint doi: https://doi.org/10.1101/2021.07.06.21260111; this version posted August 29, 2021. The copyright holder for this preprint (which was not certified by peer review) is the author/funder, who has granted medRxiv a license to display the preprint in perpetuity.

All rights reserved. No reuse allowed without permission.

qualitg/8f life, fatigue, pain intensity, quality of sleep, anxiety, and depression in patients with1丹Bßomyalgia syndrome. Disabil Rehabil. 2019;41(19):2235-2246.

232.194Qarmiento-Hernández I, Pérez-Marín MLÁ, Nunez-Nagy S, Pecos-Martín D, GallegoIzquîg-tb T, Sosa-Reina MD. Effectiveness of Invasive Techniques in Patients with FibräAfalgia: Systematic Review and Meta-Analysis. Pain Med. 2020;21(12):3499-3511. 233.194Beare JC, Zheng Z, Xue CC, Liu JP, Shang J, Scott SW, Littlejohn G. Acupuncture for treatigf(fibromyalgia. Cochrane Database Syst Rev. 2013; 2013(5):CD007070.

234.1948hang XC, Chen H, Xu WT, Song YY, Gu YH, Ni GX. Acupuncture therapy for fibro1946lgia: a systematic review and meta-analysis of randomized controlled trials. J Pain Res.109179; 12:527-542.

235.1948iu L, Huang QM, Liu QG, et al. Evidence for Dry Needling in the Management of Myof8steal Trigger Points Associated With Low Back Pain: A Systematic Review and MetaAnal/3ESO Arch Phys Med Rehabil. 2018;99(1):144-152.e2.

236.195Dong Z, Shun-Yue L, Shu-You W, Hui-Min M. Evaluation of influence of acupuncture and 395Caro-acupuncture for blood perfusion of stomach by laser Doppler blood perfusion imagjig్g3Evid Based Complement Alternat Med. 2011; 2011:969231.

237.1954i X, Wang R, Xing X, et al. Acupuncture for Myofascial Pain Syndrome: A Network Meta955alysis of 33 Randomized Controlled Trials. Pain Physician. 2017;20(6):E883-E902. 238.195®origo B, Bartoli V, Grisillo D, Beconi D. Fibrositic myofascial pain in intermittent claudy

$6(2) \cdot 119558190$.

239.1959omàs M, Garcia N, Santafé MM, Lanuza M, Tomàs J. Protein kinase C involvement in the9terenoline release reduction induced by amyloid-beta(25-35) aggregates on neur̉of6iscular synapses. J Alzheimers Dis. 2009;18(4):877-84. 
medRxiv preprint doi: https://doi.org/10.1101/2021.07.06.21260111; this version posted August 29, 2021. The copyright holder for this preprint (which was not certified by peer review) is the author/funder, who has granted medRxiv a license to display the preprint in perpetuity.

All rights reserved. No reuse allowed without permission.

240.196Revy Nogueira M, Hamraz M, Abolhassani M, et al. Mechanical stress increases brain amyld633, tau, and $\alpha$-synuclein concentrations in wild-type mice. Alzheimers Dement.

2018,9644):444-453.

241.196Drabik D, Chodaczek G, Kraszewski S. Effect of Amyloid- $\beta$ Monomers on Lipid

Menß166fne Mechanical Parameters-Potential Implications for Mechanically Driven

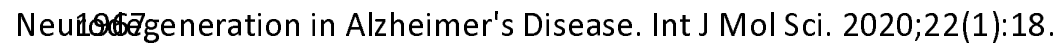

242.196\&ellermayer MS, Grama L, Karsai A, et al. Reversible mechanical unzipping of amyloid betał日69ils. J Biol Chem. 2005;280(9):8464-70.

243.197 Bigot M, Chauveau F, Amaz C, Sinkus R, Beuf O, Lambert SA. The apparent mecthanical effect of isolated amyloid $-\beta$ and $\alpha$-synuclein aggregates revealed by multifrequ鿉y MRE. NMR Biomed. 2020;33(1):e4174.

244.197 Chiasseu M, Cueva Vargas JL, Destroismaisons L, Vande Velde C, Leclerc N, Di Polo A. Tau A\&Zamulation, Altered Phosphorylation, and Missorting Promote Neurodegeneration in Glauran5a. J Neurosci. 2016;36(21):5785-98.

245.1976onti PC, Costa YM, Goncalves DA, Svensson P. Headaches and myofascial tem $\not \mathbf{\theta} \nabla \mathbf{\partial m a n d i b u l a r}$ disorders: overlapping entities, separate managements? J Oral Rehabil 2016,94\$(9): 702-15.

246.197@astro-Sanchez AM, Garcia-Lopez H, Mataran-Penarrocha GA, et al. Effects of Dry Need98g on Spinal Mobility and Trigger Points in Patients with Fibromyalgia Syndrome. Pain Phys19i8m. 2017;20(2):37-52.

247.198Alonso-Blanco C, Fernández-de-las-Peñas C, Morales-Cabezas M, Zarco-Moreno P, Ge H\$M,\&Borez-García M. Multiple active myofascial trigger points reproduce the overall spontere pain pattern in women with fibromyalgia and are related to widespread mecth985cal hypersensitivity. Clin J Pain. 2011; 27(5):405-13. 
248 1986e HY, Wang Y, Danneskiold-Samsøe B, Graven-Nielsen T, Arendt-Nielsen L. The predk987mined sites of examination for tender points in fibromyalgia syndrome are freq®e88ly associated with myofascial trigger points. J Pain. 2010;11(7):644-51.

249.198\$ourgaize S, Janjua I, Murnaghan K, Mior S, Srbely J, Newton G. Fibromyalgia and myof 990 al pain syndrome: Two sides of the same coin? A scoping review to determine the lexiç99df the current diagnostic criteria. Musculoskeletal Care. 2019;17(1):3-12.

250.199Xu Y, Hu J, Yilmaz DE, Bachmann S. Connexin43 is differentially distributed within rena1993culature and mediates profibrotic differentiation in medullary fibroblasts. Am J Phys189Aenal Physiol. 2021;320(1):F17-F30.

251.199\$iragoli M, Gaudesius G, Rohr S. Electrotonic modulation of cardiac impulse condi966on by myofibroblasts. Circ Res. 2006;98(6):801-10.

252.1997guchi M, Hara M, Manome H, Kobayasi H, Tagami H, Aiba S. Communication netw8 humE99Bair follicles. Exp Dermatol. 2003;12(3):283-8.

253200Quo M, Luo Y, Mao N, et al. Cancer-Associated Fibroblasts Accelerate Malignant Progze日sion of Non-Small Cell Lung Cancer via Connexin 43-Formed Unidirectional Gap Junctronal Intercellular Communication. Cell Physiol Biochem. 2018;51(1):315-336.

2542003̧abbiani G, Chaponnier C, Hüttner I. Cytoplasmic filaments and gap junctions in epit国和 cells and myofibroblasts during wound healing. J Cell Biol. 1978;76(3):561-8. 255.2005panakis SG, Petridou S, Masur SK. Functional gap junctions in corneal fibroblasts and 2006fibroblasts. Invest Ophthalmol Vis Sci. 1998;39(8):1320-8

2562007Noodward TL, Sia MA, Blaschuk OW, Turner JD, Laird DW. Deficient epithelialfibrot0last heterocellular gap junction communication can be overcome by co-culture with an inte日0Q9liate cell type but not by E-cadherin transgene expression. J Cell Sci. 1998;111 ( Pt 23):3010-39. 
medRxiv preprint doi: https://doi.org/10.1101/2021.07.06.21260111; this version posted August 29, 2021. The copyright holder for this preprint (which was not certified by peer review) is the author/funder, who has granted medRxiv a license to display the preprint in perpetuity.

All rights reserved. No reuse allowed without permission.

257201 Neuhaus J, Gonsior A, Cheng S, Stolzenburg JU, Berger FP. Mechanosensitivity Is a Charezeristic Feature of Cultured Suburothelial Interstitial Cells of the Human Bladder. Int J Mol bei132020;21(15):5474.

258.2014embong J, Sabass B, Sun B, Rogers ME, Stone HA. Mechanics regulates ATPstim20atte collective calcium response in fibroblast cells. J R Soc Interface. 201201\$108):20150140.

259.2017keda Y, Fry C, Hayashi F, Stolz D, Griffiths D, Kanai A. Role of gap junctions in spon2andous activity of the rat bladder. Am J Physiol Renal Physiol. 2007;293(4):F1018-25. 2602019euhaus J, Pfeiffer F, Wolburg H, Horn LC, Dorschner W. Alterations in connexin expreqzion in the bladder of patients with urge symptoms. BJU Int. 2005;96(4):670-6. 261202Askar SF, Bingen BO, Swildens J, et al. Connexin43 silencing in myofibroblasts prevenz arrhythmias in myocardial cultures: role of maximal diastolic potential. Cardiovasc Res.200212;93(3):434-44.

262.202đI lochiver S, Muñoz V, Vikstrom KL, Taffet SM, Berenfeld O, Jalife J. Electrotonic myo 1025 blast-to-myocyte coupling increases propensity to reentrant arrhythmias in twodime086nal cardiac monolayers. Biophys J. 2008;95(9):4469-80

263202Paw M, Borek I, Wnuk D, et al. Connexin43 Controls the Myofibroblastic Diffęez8iation of Bronchial Fibroblasts from Patients with Asthma. Am J Respir Cell Mol Biol. 2012,5291):100-110.

264 2030lagaraju CK, Dries E, Gilbert G, et al. Myofibroblast modulation of cardiac myocyte strueQBథ 1 and function. Sci Rep. 2019;9(1):8879.

265203Daniel EE, Yazbi AE, Mannarino M, et al. Do gap junctions play a role in nerve tranz0ß3ssions as well as pacing in mouse intestine? Am J Physiol Gastrointest Liver Physiol. 2002,034(3):G734-45.

266203\$ewe M, Bauer CK, Schwarz JR, Middendorff R. Mechanisms regulating spor2aBre ous contractions in the bovine epididymal duct. Biol Reprod. 2006;75(4):651-9. 
medRxiv preprint doi: https://doi.org/10.1101/2021.07.06.21260111; this version posted August 29, 2021. The copyright holder for this preprint (which was not certified by peer review) is the author/funder, who has granted medRxiv a license to display the preprint in perpetuity.

All rights reserved. No reuse allowed without permission.

267203 Grand T, Salvarani N, Jousset F, Rohr S. Aggravation of cardiac myofibroblast arrhұđBrogeneicity by mechanical stress. Cardiovasc Res 2014; 104(3): 489-500.

268.203פguyen TP, Xie Y, Garfinkel A, Qu Z, Weiss JN. Arrhythmogenic consequences of myofoblast-myocyte coupling. Cardiovasc Res 2012; 93(2): 242-51.

269 204Mercier F, Hatton GI. Connexin 26 and basic fibroblast growth factor are expressed prim20 42 in the subpial and subependymal layers in adult brain parenchyma: roles in stem cell paokfferation and morphological plasticity? J Comp Neurol. 2001;431(1):88-104.

270.2044Grafstein B, Liu S, Cotrina ML, Goldman SA, Nedergaard M. Meningeal cells can com2045icate with astrocytes by calcium signaling. Ann Neurol. 2000;47(1):18-25.

2712046)ercier F, Hatton GI. Immunocytochemical basis for a meningeo-glial network. J ComzoNểurol. 2000;420(4):445-65.

2722048rafstein B, Liu S, Cotrina ML, Goldman SA, Nedergaard M. Meningeal cells can com2049icate with astrocytes by calcium signaling. Ann Neurol. 2000;47(1):18-25.

273.2050heng N, Yuan XY, Chi YY, et al . The universal existence of myodural bridge in man2051s: an indication of a necessary function. Sci Rep. 2017;7(1):8248

274205Zollonier L, Schaub S, Meister JJ, Hinz B. Myofibroblast communication is controlled by in205Bellular mechanical coupling. J Cell Sci. 2008;121(Pt 20):3305-16.

2752054amelliti P, Green CR, LeGrice I, KohI P. Fibroblast network in rabbit sinoatrial node: stru2055I and functional identification of homogeneous and heterogeneous cell coupling.

Circ Pas62004;94(6):828-35.

276.205Murata K, Hirata A, Ohta K, Enaida H, Nakamura KI. Morphometric analysis in mouse scler20 58 roblasts using focused ion beam/scanning electron microscopy. Sci Rep.

2012,959):6329.

2772060 brahim MM, Chen L, Bond JE, et al. Myofibroblasts contribute to but are not neceraty for wound contraction. Lab Invest. 2015;95(12):1429-38. 
278.206https://www.uptodate.com/contents/somatic-symptom-disorder-epidemiologyand-2068cal-

presefation?search=somatic\%20symptom\%20disorder\&source=search_result\&selectedTitl e=1208\&usage_type=default\&display_rank=1\#H3058265287

By Järes L. Levenson, Accessed January 2021

279206T. Gilbert. Breathing: the legacy of Wilhelm Reich. J. Bodyw. Mov. Ther. 1999; 3:97106.2068

2802069lexander Lowen, Leslie Lowen. The Way to Vibrant Health: A Manual of Bioeze7Q6etic Exercises. New York; Harper \& Row 1977.

281.207Nakaya M, Watari K, Tajima M, et al. Cardiac myofibroblast engulfment of dead cells facilizazes recovery after myocardial infarction. J Clin Invest. 2017;127(1):383-401.

2822075aada JI, Pinchuk IV, Barrera CA, et al. Subepithelial myofibroblasts are novel nonparffssional APCs in the human colonic mucosa. J Immunol. 2006;177(9):5968-79. 283.2074 Duc2aOA6denocarcinoma Reveals Antigen-Presenting Cancer-Associated Fibroblasts. Cancer Disc2072019;9(8):1102-1123.

284207\$ang M, Xia J, Wu X, et al. Adenosine signaling inhibits CIITA-mediated MHC class II

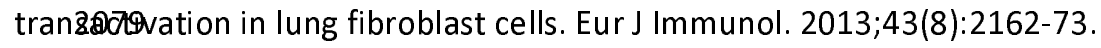

285208Boots AM, Wimmers-Bertens AJ, Rijnders AW. Antigen-presenting capacity of rheura8tloid synovial fibroblasts. Immunology. 1994;82(2):268-74.

286.208Applbaum E, Lichtbroun A. Novel Sjögren's autoantibodies found in fibromyalgia pati20833with sicca and/or xerostomia. Autoimmun Rev. 2019;18(2):199-202.

287 2084acobsen S, Høyer-Madsen M, Danneskiold-Samsøe B, Wiik A. Screening for auto 208 Bbodies in patients with primary fibromyalgia syndrome and a matched control groupostPMIS. 1990;98(7):655-8. 
medRxiv preprint doi: https://doi.org/10.1101/2021.07.06.21260111; this version posted August 29, 2021. The copyright holder for this preprint (which was not certified by peer review) is the author/funder, who has granted medRxiv a license to display the preprint in perpetuity. All rights reserved. No reuse allowed without permission.

288.2087ounger JW, Shen YF, Goddard G, Mackey SC. Chronic myofascial

tempo88mandibular pain is associated with neural abnormalities in the trigeminal and limbic syst20899Pain. 2010;149(2):222-228.

289.2090ari E, Oztay F, Tasci AE. Vitamin D modulates E-cadherin turnover by regulating

TGF-2001d Wnt signalings during EMT-mediated myofibroblast differentiation in A459 cells. J

SteranEBiochem Mol Biol. 2020;202:105723. 